Review

\title{
Gaseous Mediators Nitric Oxide and Hydrogen Sulfide in the Mechanism of Gastrointestinal Integrity, Protection and Ulcer Healing
}

\author{
Marcin Magierowski, Katarzyna Magierowska, Slawomir Kwiecien and Tomasz Brzozowski * \\ Department of Physiology, Jagiellonian University Medical College, Cracow 31-531, Poland; \\ E-Mails: magierowskim@yahoo.pl (M.M.); k.jasnos@interia.pl (K.M.); \\ skwiecien@cm-uj.krakow.pl (S.K.) \\ * Author to whom correspondence should be addressed; E-Mail: mpbrzozo@cyf-kr.edu.pl; \\ Tel.: +48-12421-1006; Fax: +48-12422-2014.
}

Academic Editor: Claudio Battilocchio

Received: 20 March 2015 / Accepted: 13 May 2015 / Published: 19 May 2015

\begin{abstract}
Nitric oxide (NO) and hydrogen sulfide $\left(\mathrm{H}_{2} \mathrm{~S}\right)$ are known as biological messengers; they play an important role in human organism and contribute to many physiological and pathophysiological processes. NO is produced from L-arginine by constitutive NO synthase (NOS) and inducible NOS enzymatic pathways. This gaseous mediator inhibits platelet aggregation, leukocyte adhesion and contributes to the vessel homeostasis. NO is known as a vasodilatory molecule involved in control of the gastric blood flow (GBF) and the maintenance of gastric mucosal barrier integrity in either healthy gastric mucosa or that damaged by strong irritants. Biosynthesis of $\mathrm{H}_{2} \mathrm{~S}$ in mammals depends upon two enzymes cystathionine- $\beta$-synthase and cystathionine $\gamma$-lyase. This gaseous mediator, similarly to NO and carbon monoxide, is involved in neuromodulation, vascular contractility and anti-inflammatory activities. For decades, $\mathrm{H}_{2} \mathrm{~S}$ has been known to inhibit cytochrome c oxidase and reduce cell energy production. Nowadays it is generally considered to act through vascular smooth muscle ATP-dependent $\mathrm{K}^{+}$channels, interacting with intracellular transcription factors and promote sulfhydration of protein cysteine moieties within the cell, but the mechanism of potential gastroprotective and ulcer healing properties of $\mathrm{H}_{2} \mathrm{~S}$ has not been fully explained. The aim of this review is to compare current results of the studies concerning the role of $\mathrm{H}_{2} \mathrm{~S}$ and $\mathrm{NO}$ in gastric mucosa protection and outline areas that may pose new opportunities for further development of novel therapeutic targets.
\end{abstract}


Keywords: nitric oxide; hydrogen sulfide; gastrointestinal tract; gastric mucosa; gastroprotection

\section{Introduction}

Gastric mucosa is constantly exposed to exogenous food products, providing vital nutrients to the human body in order to maintain physiological homeostasis. Unfortunately, many of these food products, harsh substances and drugs delivered via the oral route can affect gastric mucosal integrity. Ethanol, nicotine and ingestion of drugs, in particular, nonsteroidal anti-inflammatory drugs (NSAIDs) (e.g., aspirin, ASA) are considered as the major causative factors in the development of acute mucosal damage and gastric ulcers [1-3]. Moreover, Helicbacter pylori infection, hyperosmolar solutions, bile salts, the exposure to chronic stress, and ischemia to the gastric tissue followed by reperfusion were all reported to act as the risk factors of peptic ulcer disease [4,5].

The physiological protective mechanisms involved in maintaining gastric mucosa integrity include epithelial cells secreting mucus and bicarbonate, the gastric blood flow (GBF) [6,7], endogenous prostaglandins (PGs) [8-11], metallothionein [12], melatonin [13] and recently discovered food intake controlling peptides such as ghrelin [14], orexin-A [15] and leptin [16]. Moreover, gaseous molecule nitric oxide (NO) and other gaseous vasoactive mediators such as hydrogen sulfide $\left(\mathrm{H}_{2} \mathrm{~S}\right)$ and carbon monoxide (CO) were shown to play an important role in the mechanism of mucosal defense and gastroprotection $[17,18]$. It is now generally accepted that gaseous mediators NO (Figure 1) and $\mathrm{H}_{2} \mathrm{~S}$ contribute to many physiological and pathophysiological processes including the maintenance of gastrointestinal (GI) integrity and the mechanism of gastroduodenal protection.

\section{Major beneficial actions of NO in the mechanism} of gastrointestinal mucosal defense

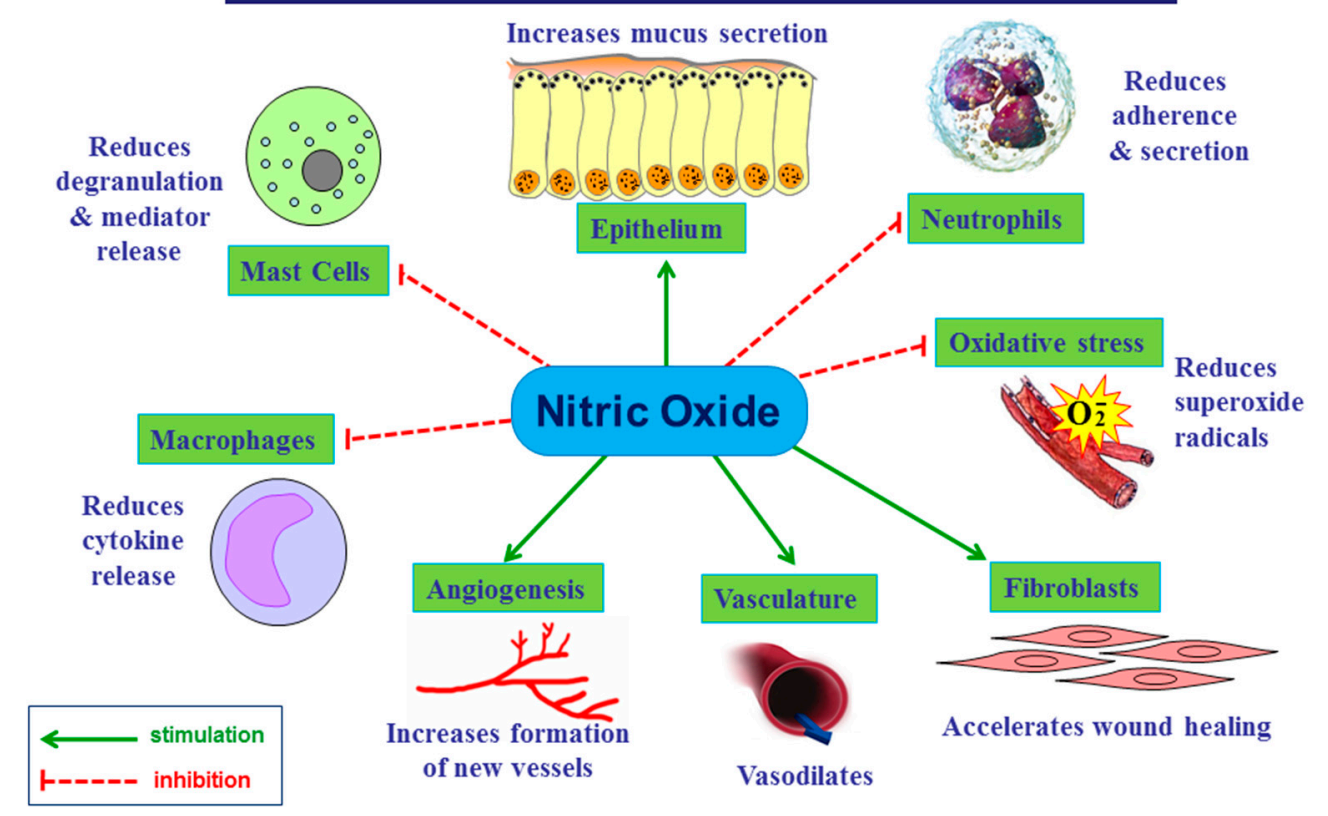

Figure 1. Beneficial actions of nitric oxide (NO) in the mechanism of gastrointestinal mucosal defense. 


\section{Biosynthesis of NO and Its Major Functions in Various Body Systems}

NO is produced and released from vascular endothelium and sensory nerve endings via the enzymatic activity of constitutive NO synthase (cNOS) and inducible NOS (iNOS) [19]. The agonists, such as acetylocholine (ACh), bradykinin or serotonin (5-HT) were shown to stimulate their membrane receptors in endothelial cells of gastric vessels and release NO [19]. A substrate for NO synthase to produce NO is amino acid L-arginine [20]. NO diffuses from endothelium to smooth muscles, located in vascular wall, where NO reacts with soluble guanylyl cyclase (sGC), leading to cellular rise of a second messenger cyclic guanosine monophosphate (cGMP). NO activates sGC, transforming guanosine triphosphate (GTP) to cGMP. This cGMP, acting via protein kinase G leads to relaxation of smooth muscle cell and subsequent increase of vessel diameter and an enhancement in the organ blood flow [8,21]. The biological action of NO may be mimic by the exogenous administration of NO donors, such as sodium nitrate, nitroprusside or other organic nitrates, the 3-morpholinosydnonimine (SIN-1), S-nitroso- $N$ acethyl-D,L-penicylamine (SNAP), gliceryl trinitrate (GTN) or NO-releasing aspirin [22,23]. Thiols (R-SH), for example, glutathione (GSH) cooperate with NO. Other vasodilators, for example, pentoxifylline (PTX) may act on smooth muscle causing their relaxation but this effect seems to be NO independent [24].

The fact that NO acts on blood vessels causing vasodilatation implies that this gaseous molecule contributes to the maintenance of gastric mucosal barrier integrity. This is supported by the observation that the inhibition of NO production by a nonspecific $\mathrm{N}^{\mathrm{G}}$-nitro-L-arginine (L-NNA) not only markedly impaired gastric secretion and gastric motility but also abolished the protective activity of gastroprotective agents [25]. Moreover, the inhibition of NOS has been shown to delay the healing of chronic gastric ulcers and diminish the restoration of the GBF at ulcer margin associated with this healing process [26]. Interestingly, the adverse effect of blockade of NOS by L-NNA or L-N ${ }^{\mathrm{G}}$-monomethyl arginine citrate (L-NMMA) on gastric integrity can be reversed by administration of L-arginine, a substrate for this enzyme, administered in the presence of this inhibitor $[21,26]$.

\section{Role of NO in the Mechanism of Gastric Integrity, Protection and Ulcer Healing}

The evidence based medicine indicate that NO, the afferent capsaicin-sensitive $\mathrm{C}$ fibers and products of cyclooxygenase (COX) activity, are major factors, involved in the maintenance of gastric mucosal integrity due to their potent role in the control of the GBF, gastroprotection and ulcer healing $[21,26]$.

Inhibition of NOS that results in a decrease in local NO production, impairs gastric microcirculation and aggravates gastric lesions induced by noxious agents. In physiological conditions, NO is produced by NOS from L-arginine, which is transformed to L-citrulline [27]. In pathological conditions, L-arginine may be involved in another metabolic pathway, catalyzed by protein arginine methyltransferase (PRMT). PRMT, in presence of proteins containing methylated arginine residues, produces asymmetric dimethylarginine (ADMA) [28]. ADMA acts as an endogenous NOS inhibitor in decreasing the NO production. Depletion of NO has multifactorial consequences and may be considered as a phenomenon in pathogenesis of numerous global diseases such as hypertension, arteriosclerosis, heart failure, chronic kidney disease, diabetes mellitus [29-32]. Then, ADMA can be metabolized to L-citrulline by enzyme dimethylarginine dimethylaminohydrolase (DDAH) [32]. 
Recently, the administration of ADMA failed to cause spontaneous gastric lesions but exacerbated gastric lesions induced by various ulcerogenes including stress and ischemia-reperfusion injury [33,34] suggesting that the inhibition of NO-synthase can increase the gastric mucosa susceptibility to damage induced by various stressors and gastric ulcerogenes.

Mechanism of beneficial action of NO-donors has been attributed to the vasodilatation induced by these agents resulting in an increase of perfusion of target organs [35]. For instance, SIN-1-induced release of NO exerted anti-atherogenic properties by alteration of low density lipoprotein (LDL) metabolism in macrophages [36]. Another NO-donor administration, $S$-nitroso- $N$-acethyl-D,L-penicylamine (SNAP), potently affected the regulation of cardiovascular system in hypertension [37]. The administration of NO-donors accelerated healing of gastric mucosa damage and experimental gastric ulcers [38]. For example, GTN attenuated damaging effect of ethanol by improvement of the changes in potential difference across the stomach wall [39]. SNAP demonstrated gastroprotective properties against ethanol-induced gastric lesions due to an increase in the GBF in this animals. Moreover, SNAP has been shown to inhibit gastric acid secretion documented in vitro in isolated parietal cells, which at least in part, may contribute to the observed gastric protection by this agent in vivo [40].

The major complication related to NSAIDs such as ASA ingestion in humans is the increased risk of adverse GI-side effects associated with their world-wide use as anti-inflammatory therapy. These adverse effects of ASA were originally attributed to the inhibition of COX and the deficiency of endogenous PGs, an increase in reactive oxygen species (ROS), lipid peroxidation and a fall in antioxidizing activities of gastric mucosa exposed to ASA [41]. The mechanism of NSAID-induced side effects is inhibition of constitutive isoform COX-1 and inducible isoform COX-2 [41]. The COX-1 plays gastroprotective role, because it produces PGs involved in protection of GI-mucosa while COX-2, which is induced but proinflammatory mediators, results in detrimental effects such as an increase of vessels permeability, pain and fever due to production of large amount of proinflammatory PGs [42,43]. The administration of non-selective COX inhibitors, e.g., ASA causes, except for therapeutic effects resulting from COX-2 inhibition, also side effects, resulting from COX-1 inhibition [42]. However, the selective inhibition of COX-2 aggravates acute gastric lesions induced by stress and ischemia-reperfusion and delays the healing of preexisting gastric ulcers [43].

A new class of NO-releasing NSAIDs was shown to inhibit COX-1 and COX-2 activity and PGE2 generation without causing mucosal damage $[22,44]$. Furthermore, NO-ASA, despite inhibition of COX enzymes was shown to protect the gastric mucosa against ethanol, stress and NSAID-induced gastric damage and accelerate the healing of gastric ulcers, mainly due to release of NO enhancing GBF [44-46]. Mechanism of this beneficial action of NO should be further investigated but NO, which is released from NO-ASA, could compensate for the inhibition of COX-1 and COX-2 activity and subsequent fall in PG synthesis induced by ASA [47]. Fiorucci et al. [48] demonstrated that NO-ASA compared with native ASA exerted sparing effect on gastric mucosa by inhibition of apoptosis and impairment of proinflammatory cytokines TNF- $\alpha$ and IL-1 $\beta$. Takeuchi et al. [49] have confirmed the protective activity of NO donating ASA against formation of gastric lesions induced by cold stress. However, the excessive release of NO from its donors could exert deleterious influence on the gastric mucosa because the application of SNAP in higher doses exaggerated ethanol-induced gastric damage [40].

The scavenging effect of these new NO derivatives of NSAID on ROS production has been demonstrated during healing of chronic gastric ulcers and this action was accompanied by a decrease 
in lipid peroxidation [50]. Wallace et al. [51] revealed that NO-ASA exhibited inhibitory effect on neutrophil adherence to the vascular endothelium and the neutrophil infiltration of gastric tissue and these effects resulted in diminishing of oxidative GI tissue damage. Neutrophils produce superoxide radical anion $\left(\mathrm{O}_{2}{ }^{-}\right)$, which belongs to group of reactive oxygen species (ROS). Superoxide radical anion reacts with cellular lipids, leading to the formation of lipid peroxides. The major anti-oxidative enzyme is superoxide dismutase (SOD). SOD catalyzes the dismutation of superoxide radical anion $\left(\mathrm{O}_{2}{ }^{--}\right)$into less noxious hydrogen peroxide $\left(\mathrm{H}_{2} \mathrm{O}_{2}\right)$, that is further degraded by catalase or glutathione peroxidase (GPx) [52,53]. The reaction of superoxide $\left(\mathrm{O}_{2}{ }^{--}\right)$with NO is however approximately three times faster than the elimination of superoxide by SOD, which could question the role of SOD in protecting NO bioavailability. Animal models have however clearly indicated that the inhibition of SOD by diethyldithiocarbamate (DETC) leads to a very significant attenuation of endothelium dependent NO-mediated vasorelaxation [53].

In contrast, Konaka et al. [54] observed an intensification of lipid peroxidation and myeloperoxidase (MPO) activity, accompanied by increase of NO production in rats with indomethacin-induced small intestinal lesions. The alternative therapy against GI lesions induced by ASA could be administration of other NO-donors because the experimental combined therapy of ASA with GTN, SIN-1, SNAP, molsidomine, sodium nitroprusside ameliorated the formation of ASA-induced gastric damage and improved the status of gastric mucosa treated with non-selective and selective COX-1and COX-2-inhibitors [52,53,55].

Disturbances in blood perfusion of gastric mucosa, during stress, result in local episodes of ischemia to the gastric tissue, followed by reperfusion and enhanced generation of ROS [56]. Previous studies revealed that ROS may cause a peroxidation of membrane lipids to lipid peroxides and impairment of cellular physiological functions leading to increased acid back-diffusion [56,57]. The determination of SOD activity and level of reduced glutathione (GSH) serve as suitable for the assessment of antioxidizing status of gastric mucosa injured by various damaging agents [57,58]. Three types of SOD can be distinguished: cytoplasmatic, mitochondrial and extracellular. SOD catalyzes the dismutation of superoxide radical anion $\left(\mathrm{O}_{2}{ }^{-}\right)$into less noxious hydrogen peroxide $\left(\mathrm{H}_{2} \mathrm{O}_{2}\right)$, that is further degraded by catalase or glutathione peroxidase. Catalase is an enzyme which accelerates degradation of $\mathrm{H}_{2} \mathrm{O}_{2}$ into water and oxygen. The second pathway of $\mathrm{H}_{2} \mathrm{O}_{2}$ metabolism depend on activity of GPx and cooperating glutathione reductase. The reduction of $\mathrm{H}_{2} \mathrm{O}_{2}$ into water by GPx is accompanied by the conversion of GSH into oxidized form (GSSG) [58]. Interestingly, NO-releasing ASA increased gastric mucosal expression of anti-oxidative enzymes SOD and GPx in rats with stress-induced gastric lesions and greatly attenuated the rise in mucosal expression and release of proinflammatory cytokines IL-1 $\beta$ and TNF- $\alpha$ [58].

\section{Role of NO in the Esophageal and Intestinal Protection}

The esophageal mucosal integrity depends upon the non-keratinized stratified squamous epithelium, hydrophobic lipid bilayer, tight junctions and intensive cell replication and regeneration after acid exposing mainly the distal esophageal mucosa [59]. Importantly, the esophagus, unlike stomach and duodenum, has no viscoelastic surface mucous layer and its epithelial cells do not secrete bicarbonate [59-61]. Consequently, the esophagus does not effectively trap of luminal bicarbonate 
allowing for a buffering gastric acid as it back diffuses from lumen toward epithelium [62]. To keep such acidity from injuring the cell, cell membrane is capable of removing excess $\mathrm{H}^{+}$from the cell and restoring $\mathrm{pH}$ to neutrality due to a sodium-dependent, chloride-bicarbonate, exchanger and a sodium-hydrogen ion exchanger of isotype-1 $[63,64]$. In esophageal epithelial cells, these transporters are localized to the basolateral membrane and include a sodium-dependent, chloride-bicarbonate, exchanger and a sodium-hydrogen ion exchanger of isotype-1 [64,65]. These barrier and transport functions of the esophageal epithelium as well as the adequate blood supply are integral processes for protection of the tissue against injury upon exposure to gastric acid [63-66].

NO and guanylate cyclase signaling were proposed to play a major role in the control of lower esophageal sphincter (LES) relaxation after stimulation of intrinsic inhibitory motor neurons [62]. In studies by Lanas et al. [67,68], the preexposure of the esophageal mucosa to acidified saline significantly decreased both the mucosal damage and the mucosal barrier dysfunction induced by acidified pepsin. The concomitant treatment with either the nitric oxide synthase inhibitor, L-NNA or the perfusion of immunospecific EGF-receptor antibodies or tyrphostin-25, an inhibitor of the tyrosine kinase activities $[67,68]$ completely reversed the protection induced by acid. They concluded that the rabbit esophageal mucosa develops mucosal adaptation to acid and pepsin dependent, at least in part, on nitric oxide and EGF-receptor-mediated mechanisms [67,68]. NO could mediate the esophagoprotective activity of certain radical scavenging substances e.g., melatonin, because the administration of L-tryptophan, a precursor of this indoleamine, or exogenous melatonin itself attenuated the esophageal damage in experimental models of rodent esophagitis [69,70]. Moreover, angiotensin-(1-7), a major vasoactive metabolite of angiotensin I, prevented the esophageal damage induced by experimental reflux esophagitis in rats via the modulation NO/NOS activity and gastric epithelial NO release [71]. In contrast, the co-administration of sodium nitrite and ascorbic acid in study by Ishiyama et al. [72] aggravated the esophageal damage compared with baseline reflux esophagitis, while the damage was unchanged when either of the reagents alone was given. This aggravatory effect of NO has been referred to the diffusion of the luminal NO into the adjacent superoxide-enriched inflamed tissue of the esophagus and excessive production of the highly toxic agent peroxynitrite, thus causing exacerbation of esophageal damage [72]. This notion was supported in their study [72] by observation that superoxide scavengers efficiently prevented the exacerbation of esophageal damage by exogenous NO exposure, suggesting an essential role of superoxide in the development of esophageal injury induced by gastric reflux. Interestingly, variations in saliva nitrite concentration in swallowed saliva failed to modify LES pressure and rate of gastric emptying and did not predispose to gastro-esophageal reflux (GERD) symptoms in humans [73]. The conventional NSAID such as ASA have been shown to augment esophagitis in experimental animals and humans but the new NSAID-releasing NO such as NO-ASA, exerted the beneficial protective effect against reflux esophagitis via the enhancement of esophageal microcirculation due to NO release and an inhibitory effect of this gaseous molecule on expression and release of pro-inflammatory cytokines [74].

Both ulcerative colitis and Crohn's disease are collectively included in the chronic intestinal disorders of inflammatory bowel diseases (IBDs) which reflect a chronic and relapsing inflammatory condition of the GI-tract [75]. The pathophysiology of IBD involve the combination of factors including patients' genetic predisposition, immune dysregulation, barrier dysfunction and the alterations in microbiota [75]. The environmental factors, such as changes in diet, stress, the use of 
antibiotics, smoking or improved domestic hygiene (e.g., eradication of intestinal helminthes) were implicated in the development and an increased prevalence of IBD world-wide [76]. The role of NO in IBD is controversial since there is evidence of proinflammatory and beneficial actions of this endogenous and exogenous gaseous molecule in the treatment of IBD [77,78]. For instance, a protective action of exogenous NO in inflammation has been suggested by demonstration the treatment with Lactobacillus farciminis, which produces NO in vitro attenuated the colonic damage in experimental TNBS-induced colitis with the extent similar to that exhibited by sodium nitroprusside (SNP), a NO donor [77]. In another study, the increased production of pro-inflammatory cytokines and NO through the inducible nitric oxide synthase (iNOS) pathway has been proposed to play a role in pathogenesis of human ulcerative colitis (UC) [78]. In their study [78], the inflamed and not inflamed mucosa from patients with severe UC were incubated with a highly selective iNOS inhibitor $1400 \mathrm{~W}$, with or without a relatively selective cNOS inhibitor L-NAME, or an NO-donor, SNAP. They concluded that NO seems to exacerbate the inflammatory response, and selective iNOS inhibition may have therapeutic promise in the treatment of UC [78]. This notion was supported by observation that the selective inhibition of iNOS besides inhibition of NO release, suppressed mucosal TNF- $\alpha$ and IL- 6 release in colonic mucosal explants of patients with active UC [78]. The protective role of NO in rodent models of experimental dextran (DSS)-induced colitis was developed by Jädert et al. [79], who revealed that inorganic nitrate and nitrite can serve as an alternative substrates for NO generation in the GI-tract. The administration of nitrate in their study [79] inhibited the disease activity score (DAI) and improved DSS-induced colitis by increasing the thickness of the protective mucus secretion in colonic mucosa. Nitrite not only alleviated inflammation associated with DSS administration but also displayed therapeutic effects by ameliorating established colonic inflammation due to the attenuation of enhanced colonic expression of iNOS and the preservation of adherent mucus layer [79]. Arginase is the endogenous inhibitor of inducible NO synthase (iNOS), that uses the same substrate, L-arginine and synthesizes ornithine, which is metabolized by the enzyme ornithine decarboxylase (ODC) to produce polyamines [80]. In a study using the same animal model of DSS-induced colitis, the administration of nor-NOHA, an inhibitor of arginase activity, ameliorated the colonic damage and the upregulation of arginase at both mRNA and protein levels, and decreased the content of L-arginine in colonic tissue [80]. As a result, the decreased concentration of $\mathrm{NO}_{\mathrm{x}}$ in colonic tissues during colitis was restored to almost normal levels [80]. These authors concluded that arginase-induced depletion of NO production could contribute to the pathogenesis of the colonic inflammation and arginase inhibition should be further considered as the therapeutic strategy in the treatment of colitis [80]. The dysbiosis of bacteria as a source of NO has been hypothesized to initiate $\mathrm{UC}$ in humans and the prolonged production of bacterial NO with sulphide could contribute to the initiation and mucosal barrier breakdown [81]. It is proposed that the production of NO by colonic bacteria and that produced by the colonic mucosa should be considered as two separate sources of NO in the lumen of lower GI-tract [81].

\section{Biosynthesis of $\mathrm{H}_{2} \mathrm{~S}$ and Its Major Functions in Various Body Systems}

$\mathrm{H}_{2} \mathrm{~S}$ is biosynthesized form L-cysteine by the activity of two main pirydoxal-5-phosphate (vitamin $\mathrm{B}_{6}$ ) dependent enzymes: cystathionine $\gamma$-lyase (CSE) and cystathionine $\beta$-synthase (CBS) (Figure 2) $[82,83]$. Moreover, $\mathrm{H}_{2} \mathrm{~S}$ may be synthesized by 3 -mercaptopyruvate sulfotransferase (3-MST) in coactivity with 
cysteine aminotransferase $[84,85] . \mathrm{H}_{2} \mathrm{~S}$ concentration in mammalian blood ranges between 30 and $100 \mu \mathrm{M}$. In the brain upper limit is $160 \mu \mathrm{M}$. Values higher than $200 \mu \mathrm{M}$ exerts toxicity [86,87].

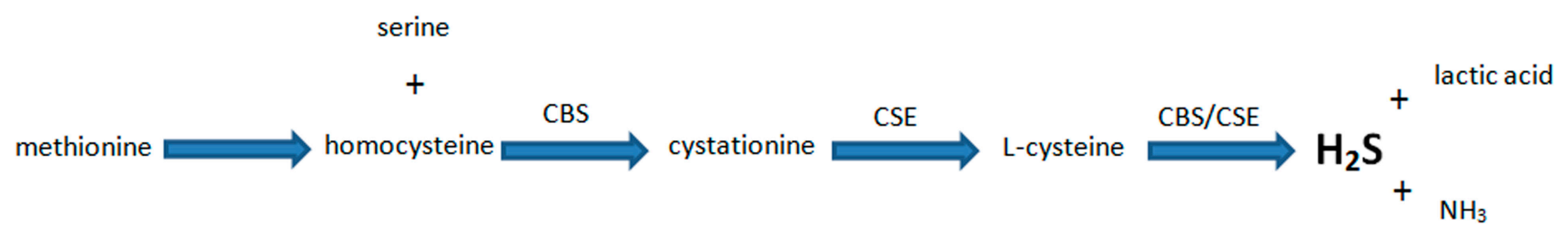

Figure 2. Simplified hydrogen sulfide synthesis pathway.

In experimental models, D, L-propargylglycine (PAG) or $\beta$-cyanoalanine are commonly used to inhibit CSE activity, whereas hydroxylamine or aminooxyacetic acid serve as a tool to inhibit CBS $[88,89]$. To increase endogenous $\mathrm{H}_{2} \mathrm{~S}$ level, researchers use precursor of the gaseous mediator synthesis, L-cysteine or a direct donors of this gaseous mediator, such as NaHS, diallyl disulfide (DADS) or Lawesson's reagent $[2,90]$.

Recent studies have shown that $\mathrm{H}_{2} \mathrm{~S}$, likewise $\mathrm{NO}$ and $\mathrm{CO}$, is involved in various physiological activities [17,87]. Those gaseous molecules indicate vasodilatory, neuromodulatory and anti-inflammatory effects $[91,92]$.

In the central nervous system, $\mathrm{H}_{2} \mathrm{~S}$ dose-dependently evokes long-term potentiation and this response is accompanied with intracellular cAMP production and NMDA-receptors activity in hippocampus [92]. Additionally, $\mathrm{H}_{2} \mathrm{~S}$ protects blood-brain barrier integrity [93] and promotes angiogenesis after cerebral ischemia [94].

In the cardiovascular system $\mathrm{H}_{2} \mathrm{~S}$ inhibits leukocytes adherence to blood vessels walls and induces vasodilatation [95]. Both abovementioned effects were abolished by glibenclamide, which suggests that $\mathrm{H}_{2} \mathrm{~S}$ physiological actions are connected with ATP-dependent potassium ion channels [96]. Interestingly, the hypotensive effect of $\mathrm{NO}$ and $\mathrm{CO}$ is linked to sGC and cGMP activation what differentiates those molecules from $\mathrm{H}_{2} \mathrm{~S}$ [97].

Many studies have been conducted to determine the role of $\mathrm{H}_{2} \mathrm{~S}$ in the treatment of inflammatory pathologies $[98,99]$. On the one hand, a pro-inflammatory action of $\mathrm{H}_{2} \mathrm{~S}$ was observed in lipopolysaccharide (LPS)-induced endotoxemia [100,101] and therapeutic administration of PAG, $\mathrm{H}_{2} \mathrm{~S}$-synthetizing enzyme inhibitor, has been shown to protect mice against acute pancreatitis associated lung injury [102]. On the other hand, many studies reported anti-inflammatory features of $\mathrm{H}_{2} \mathrm{~S}$ [99]. The ability of $\mathrm{H}_{2} \mathrm{~S}$ to reduce inflammation has been demonstrated in a variety of animal models, including mice burn injury [103], rat model of colitis [104] and carrageenan-induced paw edema [105]. $\mathrm{H}_{2} \mathrm{~S}$ can evoke anti-inflammatory and pro-inflammatory effects depending on lower and higher concentration, respectively [95,105].

In the GI system $\mathrm{H}_{2} \mathrm{~S}$ remains important in the regulation of local homeostasis and may be physiological factor with an essential role in gastric mucosal defense mechanisms.

\section{Involvement of $\mathrm{H}_{2} \mathrm{~S}$ in the Mechanism of Gastroprotection and Ulcer Healing}

It has been demonstrated that $\mathrm{H}_{2} \mathrm{~S}$ protects GI tract against gastric damage induced by various factors [89]. Wallace et al. [106] showed that COXs inhibitors in combination with $\mathrm{H}_{2} \mathrm{~S}$ donor can 
attenuate gastric mucosal lesions in stomach induced by NSAID, such as naproxen or ASA. It has been shown that $\mathrm{H}_{2} \mathrm{~S}$ releasing derivatives of NSAID have reduced side effects within GI tract comparing with native forms of this agents [107]. These results were confirmed by Liu et al. [108] by demonstration that the novel $\mathrm{H}_{2} \mathrm{~S}$-releasing derivative of this anti-inflammatory drug attenuated gastric lesions induced by conventional ASA.

Cipriani et al. [109] demonstrated that protective action of $\mathrm{H}_{2} \mathrm{~S}$ is accompanied with the activity of bile acid receptor (GPBAR1) since GPBAR1 agonists protected gastric mucosa against injury induced by ASA and other NSAIDs in a COX-independent manner. Administration of PAG reversed these effects. It was concluded that GPBAR1 and $\mathrm{H}_{2} \mathrm{~S}$ are essential to maintain GI tract integrity against exposure to damaging factors [109].

Lou et al. [110] demonstrated that $\mathrm{H}_{2} \mathrm{~S}$ decreases the concentration of the lipid peroxidation products in gastric mucosa and average gastric mucosa lesion number in the animal model of the water immersion and restraint stress. Our recent study revealed that endogenous PGs and afferent sensory nerves are involved in gastroprotective effect of $\mathrm{H}_{2} \mathrm{~S}$ against stress-induced gastric damage [111]. Moreover, $\mathrm{H}_{2} \mathrm{~S}$ dose-dependently exerted protective activity within the rat gastric mucosal cells (RGM1) against $\mathrm{H}_{2} \mathrm{O}_{2}$-induced oxidative damage. Involvement of mitogen-activated kinases (MAP) in $\mathrm{H}_{2} \mathrm{~S}$ gastroprotection was observed. After inhibition of c-Jun $N$-terminal kinases (JNK) activated by oxidative stress and involved in apoptosis process, protective effect of NaHS was abolished. JNK-dependent intracellular signaling pathway is involved in protective action of $\mathrm{H}_{2} \mathrm{~S}$ released from $\mathrm{NaHS}$, although, a relative effect was not observed during inhibition of particular isoforms of p38 proteins which have similar function to JNK [112]. Taken together, $\mathrm{H}_{2} \mathrm{~S}$ exerts anti-oxidative activity and plays an important role in protection of gastric mucosa epithelial cells against oxidative stress via MAP kinases activation.

In our own study, we observed that NaHS, the donor of $\mathrm{H}_{2} \mathrm{~S}$, administered intragastrically in graded doses ranging from $0.1 \mathrm{mg} / \mathrm{kg}$ up to $5 \mathrm{mg} / \mathrm{kg} 30 \mathrm{~min}$ before application of $75 \%$ ethanol significantly reduced the area of gastric damage with the highest dose of $5 \mathrm{mg} / \mathrm{kg}$ being not more effective than $1 \mathrm{mg} / \mathrm{kg}$ of this donor (Figure 3). Interestingly, Chávez-Piña et al. [3] demonstrated that PAG reduced ethanol-induced gastric lesions area comparing to NaHS-treated group and saline treated control groups with and without exposure to ethanol. Increased concentration of $\mathrm{H}_{2} \mathrm{~S}$ was measured in gastric mucosa of rats exposed to ethanol comparing with saline treated animals. Inhibition of CSE by PAG resulted in decrease of gastric lesions area and $\mathrm{H}_{2} \mathrm{~S}$ concentration. It is worth emphasizing that indomethacin inhibited the effect of PAG suggesting that PAG-induced gastroprotection could depend upon the generation of endogenous PGs [3]. We assume that there is a threshold level of $\mathrm{H}_{2} \mathrm{~S}$ concentration in the tissue which determines if this gaseous molecule exerts beneficial or harmful effects in gastric mucosa. Further studies are certainly required to prove the role of this endogenous gaseous molecule in gastroprotection against necrotizing types of injury induced by ethanol.

The undisturbed GBF is very important in homeostasis of the GI tract. As mentioned above in this review, the dysfunction of GBF may lead to initiation of gastric perturbations including mucosal lesions. Kubo et al. [113] observed that exposure to high and low concentrations of NaHS induced vasorelaxation and vasoconstriction, respectively, in isolated gastric blood vessels. Moreover, the contractile effect was accompanied by the inhibition of NOS and the endothelium-derived hyperpolarizing factor (EDHF). The relaxation of the blood vessels was partially inhibited by glibenclamide administration. Additionally, intravenous injection of NaHS increased GBF in rats [113]. We can assume that with 
partial involvement of ATP-activated calcium ion channels $\mathrm{H}_{2} \mathrm{~S}$ takes part in relaxation of blood vessels in GI tract [113].

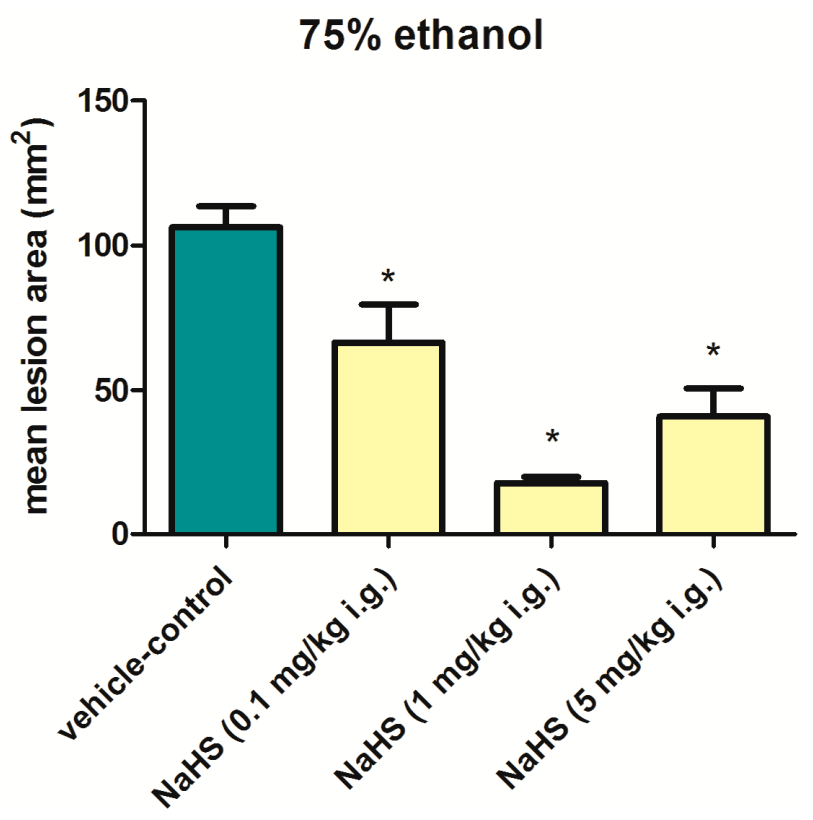

Figure 3. Mean lesions area of rats' gastric mucosa exposed to $75 \%$ ethanol. Thirty minutes before intragastric (i.g.) application of $75 \%$ ethanol, animals were pretreated with saline or NaHS $(0.1-5 \mathrm{mg} / \mathrm{kg})$. Results are mean \pm S.E.M of 6 rats per each group. Asterisk indicates significant $(p<0.05)$ difference in mean lesions area as compared with vehicle-control group.

It was shown that L-cysteine and NaHS exert gastroprotection in animal model of ischemia/ reperfusion-induced gastric injury [114]. The mechanism was accompanied by the decrease of mRNA expression for pro-inflammatory cytokines, such as IL-10 or TGF- $\beta$ in blood samples observed after application of $\mathrm{H}_{2} \mathrm{~S}$ precursor and donor while PAG reversed this effect [114]. NaHS also prevented I/R-induced oxidative stress and inflammation by decrease in MDA content, increase in GSH level and decrease of NO, IL-6 and TNF- $\alpha$ secretion in gastric mucosa [115]. $\mathrm{H}_{2} \mathrm{~S}$ significantly attenuated p38 and JNK proteins activity stimulated after exposure of gastric mucosa to ischemia and reperfusion [115]. It was shown that $\mathrm{H}_{2} \mathrm{~S}$ exerts antioxidant effect via Keap1 s-sulfhydration induced Keap1/Nrf2 disassociation and Nrf2 activation [115]. L-cysteine protected gastric mucosa against ischemia-reperfusion injury by enhancing the anti-oxidative capacity of the tissue through increasing GSH and SOD levels [116].

It has been shown that NaHS and L-cysteine reduced distention-induced gastric acid secretion while L-NAME, an inhibitor of NO biosynthesis reduced this effect, which suggests the involvement of NO in mediating the antisecretory effect of $\mathrm{H}_{2} \mathrm{~S}$ [117]. However, Takeuchi et al. [118] reported that $\mathrm{H}_{2} \mathrm{~S}$ released from NaHS increased $\mathrm{HCO}_{3}{ }^{-}$secretion in the stomach. This effect was mediated by capsaicin-sensitive afferent neurons and dependent on NO and PGs, but not by ATP-sensitive $\mathrm{K}^{+}$ channels. Nicolau et al. [119] demonstrated that Lawesson's reagent, $\mathrm{H}_{2} \mathrm{~S}$ donor protects gastric mucosa against alendronate-induced gastric damage by reduced lipid peroxidation as confirmed by a decrease in malonyldialdehyde (MDA) formation and MPO activity, increased GSH level, and reduced concentration of TNF- $\alpha$ and IL-1 $\beta$ in gastric tissue. Interestingly, in this case, glibenclamide reversed 
beneficial effect of Lawesson's reagent suggesting involvement of $\mathrm{K}^{+}$-ATP channels activity in $\mathrm{H}_{2} \mathrm{~S}$ gastroprotection against alendronate-induced injury.

The therapeutic efficacy of $\mathrm{H}_{2} \mathrm{~S}$ was taken into the consideration because $\mathrm{H}_{2} \mathrm{~S}$-releasing derivatives of drugs were developed. It has been shown that $\mathrm{H}_{2} \mathrm{~S}$-releasing aspirin (ACS14) caused reduced gastric damage as compared with standard form of the drug [108]. Wallace et al. [120] demonstrated that $\mathrm{H}_{2}$ S-releasing derivative of naproxen (ATB-346) exhibits anti-inflammatory properties similar to naproxen while gastrointestinal toxicity of this agent is reduced. Moreover, Wallace et al. [90] demonstrated that Lawesson's reagent administration accelerated gastric ulcer healing in experimental model. Taken together, gastroprotective activity of $\mathrm{H}_{2} \mathrm{~S}$ combined with NSAIDs could be an attractive option in the future as the new alternative anti-inflammatory therapy in human subjects taking native NSAIDs with complicated upper and lower GI disorders (Figure 4).

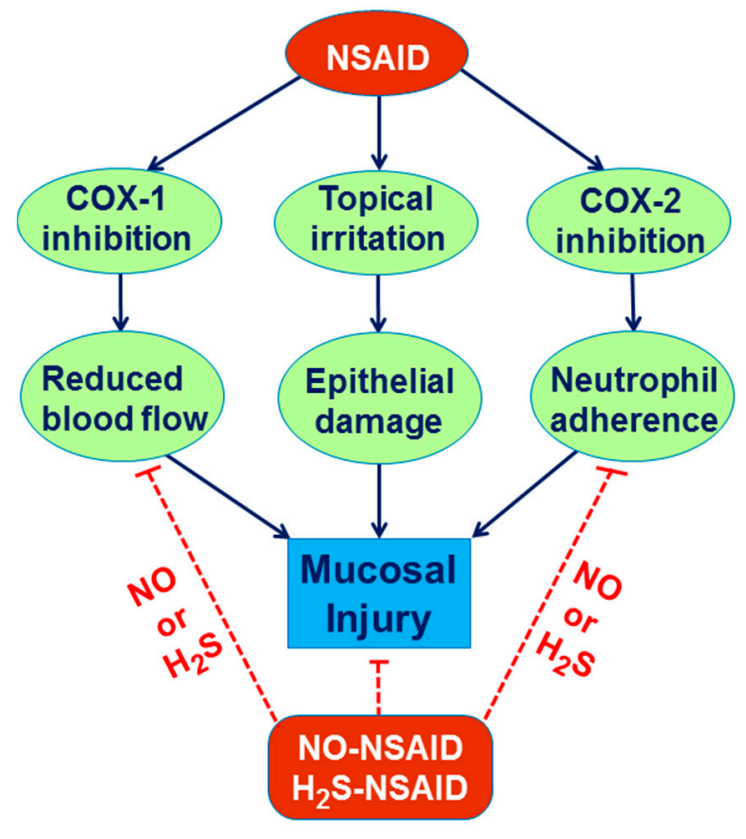

Figure 4. $\mathrm{NO}$ and $\mathrm{H}_{2} \mathrm{~S}$ gastroprotection against NSAID-induced gastric damage.

\section{Role of $\mathrm{H}_{2} \mathrm{~S}$ in the Esophageal and Intestinal Protection}

Wallace et al. [121] have suggested that enteric bacteria may be main source of $\mathrm{H}_{2} \mathrm{~S}$ in GI tract. The molecule can be alternative for oxygen for mitochondrial respiration. Diffusion of $\mathrm{H}_{2} \mathrm{~S}$ released from bacteria into the subepithelial area is controlled by enterocytes and colonocytes. This interaction could be important to modulate mucosal function and integrity. $\mathrm{H}_{2} \mathrm{~S}$ was shown to inhibit spontaneous contractile activity of smooth muscle cells in rat stomach and jejunum [122].

$\mathrm{H}_{2} \mathrm{~S}$ evokes $\mathrm{Cl}^{-}$ion secretion by activating $\mathrm{Ca}^{2+}$ and ATP-sensitive $\mathrm{K}^{+}$channels, what was demonstrated in rat colon [123]. Moreover, it has been shown that $\mathrm{NaHS}$ dose-dependently increases $\mathrm{HCO}_{3}{ }^{-}$ion secretion in rat's small intestine. This ions are important compound of natural protective alkaline mucus neutralizing acidic gastric contents which enters the duodenum from the stomach. Ise et al., demonstrated that NaHS increased bicarbonate secretion after $\mathrm{HCl}(10 \mathrm{mmol} / \mathrm{L})$ infusion into rat duodenum. Glibenclamide did not inhibited this effect what confirms that the mechanism may not 
depend on potassium channels activity. PAG decreased secretion of protective bicarbonates as compared to control group [124].

It has been shown that $\mathrm{H}_{2} \mathrm{~S}$ protected the small intestine against dextran sodium sulfate (DSS)-induced colitis in mice [125]. Administration of PAG significantly increased the intestinal damage score observed as a bleeding, changes in a stool consistency and a weight loss. This effect was accompanied by the neutrophil activation observed as the increased MPO activity while $\mathrm{H}_{2} \mathrm{~S}$ donors reduced this effect [125]. $\mathrm{H}_{2} \mathrm{~S}$ exerted cytoprotection against trinitrobenzenesulfonic acid (TNBS)-induced colonic damage via excitation of sensory nerves and activation of $\mathrm{Ca}(\mathrm{v}) 3.2 \mathrm{~T}$-type $\mathrm{Ca}^{2+}$ channels [126]. Moreover, $\mathrm{H}_{2} \mathrm{~S}$ donors such as allyl sulfides from garlic reduced the severity of the colitis in experimental models [127-129].

Flannigan et al. [130] demonstrated that hyperhomocysteinemia exacerbated colitis what was accompanied by decreased colonic $\mathrm{H}_{2} \mathrm{~S}$ synthesis cross-regulated by IL-10 production in colonic tissue suggesting that the IL-10/ $\mathrm{H}_{2} \mathrm{~S}$ signaling pathway could be promising target in therapy of inflammatory bowel disease.

We cannot exclude potent therapeutic value of $\mathrm{H}_{2} \mathrm{~S}$ against e.g., gastroesophageal reflux disease (GERD) and Barrett's disease since Zayachkivska et al. [131] have demonstrated that $\mathrm{H}_{2} \mathrm{~S}$ serves as a protective factor against non-erosive esophagitis The protective effect of $\mathrm{H}_{2} \mathrm{~S}$ against esophagitis and GERD in humans await further experimental and clinical studies.

\section{Experimental Section}

The study was approved by the Institutional Animal Care and Use Committee of Jagiellonian University Medical College in Cracow (Country) and run in accordance with the statements of the Helsinki Declaration regarding handling of experimental animals. Male Wistar rats with weight averaging about $250 \mathrm{~g}$ were used in this study. Animals were fasted for $24 \mathrm{~h}$ with free access to drinking water before the experiment. $30 \mathrm{~min}$ before application of $75 \%$ ethanol, rats were randomly selected into the groups and were pretreated i.g. with: (1) vehicle (saline; $1 \mathrm{~mL} / \mathrm{rat}$ ) and (2) NaHS applied in graded doses ranging from $0.1 \mathrm{mg} / \mathrm{kg}$ up to $5 \mathrm{mg} / \mathrm{kg}$. One hour after application of $75 \%$ ethanol, animals were anesthetized with pentobarbital $(60 \mathrm{mg} / \mathrm{kg}$ i.p.) and sacrificed by cervical dislocation, the abdomen was opened and the stomach was removed to determine the area of gastric lesions by computerized planimetry (Morphomat, Carl Zeiss, Berlin, Germany) by the person who did not know to whom experimental group animals belonged to [7,33].

\section{Conclusions}

According to the studies cited above, we can conclude that $\mathrm{H}_{2} \mathrm{~S}$ as a gaseous mediator plays an important role in many physiological aspects in human body, especially within particular parts of digestive system (Figure 5). In this review article, we focused on potent involvement of the molecule in gastroprotection and maintenance of gastric mucosal integrity.

$\mathrm{H}_{2} \mathrm{~S}$ takes part in natural prevention against many disorders of the digestive system but activity of this molecule in GI tract depends on the concentration of this gaseous mediator in particular tissues. Thus, it is very important to improve methods which help to determine precisely the threshold value of $\mathrm{H}_{2} \mathrm{~S}$ in tissues. 


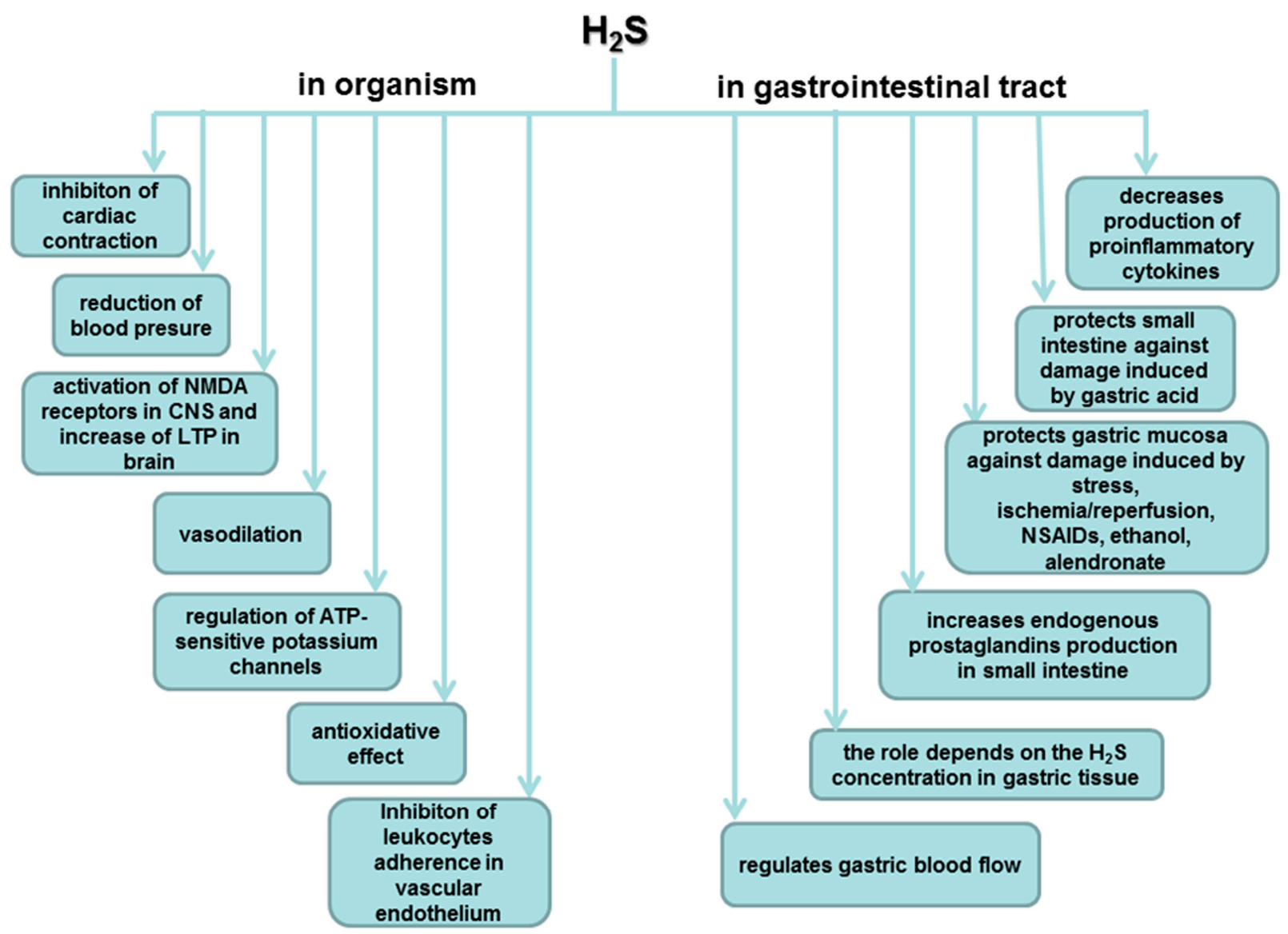

Figure 5. Role of hydrogen sulfide in organism and in gastrointestinal tract.

To summarize, recently published data cited in this article, demonstrated that $\mathrm{H}_{2} \mathrm{~S}$ serve as an important physiological molecules within GI tract. $\mathrm{H}_{2} \mathrm{~S}$ and $\mathrm{NO}$ activity is connected with complex mechanisms (Table 1). These molecules maintain the integrity of gastric mucosa and exert gastroprotection by reducing lesion area caused by various damaging factors within GI tract. Although to clearly determine the protective role of these molecules it is necessary to conduct more studies concerning these aspects and corresponding to already present data.

Table 1. Nitric oxide and hydrogen sulfide biochemistry and physiology.

\begin{tabular}{|c|c|c|c|c|}
\hline & Nitric oxide & Reference & Hydrogen sulfide & Reference \\
\hline \multicolumn{5}{|c|}{ Physiological concentrations } \\
\hline $\begin{array}{c}\text { serum } \\
\text { brain/tissue } \\
\text { toxic }\end{array}$ & $\begin{array}{c}1 \mathrm{nM} \\
100-250 \mathrm{nM} \\
0.5 \mu \mathrm{M}\end{array}$ & $\begin{array}{l}{[132]} \\
{[133]} \\
{[134]}\end{array}$ & $\begin{array}{c}30-100 \mu \mathrm{M} \\
50-160 \mu \mathrm{M} \\
250 \mu \mathrm{M} \\
\end{array}$ & [106] \\
\hline \multicolumn{5}{|c|}{ Biochemical properties } \\
\hline $\begin{array}{c}\text { Half-life } \\
\text { Physiological } \\
\text { forms } \\
\end{array}$ & $\begin{array}{l}\text { Seconds - minutes } \\
\text { NO exists as a free } \\
\text { radical } \\
\end{array}$ & $\begin{array}{l}{[135]} \\
{[136]}\end{array}$ & $\begin{array}{c}\text { Seconds } \\
20 \% \text { exist as } \mathrm{H}_{2} \mathrm{~S}, 80 \% \text { as } \mathrm{HS}^{-} \text {, trace } \\
\text { amounts of } \mathrm{S}^{2-} \\
\end{array}$ & $\begin{array}{l}{[135]} \\
{[137]}\end{array}$ \\
\hline
\end{tabular}


Table 1. Cont.

\begin{tabular}{|c|c|c|c|c|}
\hline & Nitric oxide & Reference & Hydrogen sulfide & Reference \\
\hline \multicolumn{5}{|c|}{ Crosstalk interaction on catalyzing enzymes } \\
\hline \multicolumn{5}{|c|}{\begin{tabular}{l|l|l}
$\mathrm{NO} \rightarrow \uparrow \mathrm{H}_{2} \mathrm{~S}$ & $\mathbf{H}_{2} \mathrm{~S} \rightarrow$ \\
\end{tabular}} \\
\hline & $\begin{array}{l}\text { NO donor increases } \\
\text { the expression and } \\
\text { activity of CSE in } \\
\text { cultured aortic smooth } \\
\text { muscle cells (SMCs) }\end{array}$ & [97] & $\begin{array}{l}\text { NaHS inhibits iNOS expression and } \\
\text { NO production in macrophage cells } \\
\text { (RAW264.7) }\end{array}$ & {$[138]$} \\
\hline & $\begin{array}{l}\text { NO cooperates with } \\
\mathrm{H} 2 \mathrm{~S} \text { via activation of } \\
\text { guanylyl cyclase and } \\
\text { increase of cGMP }\end{array}$ & \multirow[t]{2}{*}{ [139] } & $\begin{array}{l}\text { NaHS treatment reduces eNOS } \\
\text { activity and expression but not nNOS } \\
\text { and iNOS in isolated rat aortas }\end{array}$ & \multirow[t]{2}{*}{ [140] } \\
\hline & $\mathrm{H}_{2} \mathrm{~S} \rightarrow \downarrow \mathbf{N O}$ & & $\mathrm{H}_{2} \mathrm{~S} \rightarrow \uparrow \mathrm{NO}$ & \\
\hline & $\begin{array}{l}\text { NO does not increase } \\
\text { the expression of } \mathrm{H}_{2} \mathrm{~S}- \\
\text { generating enzymes } \\
\text { and the } \mathrm{H}_{2} \mathrm{~S} \text { level in } \\
\text { endothelial cells. }\end{array}$ & [141] & $\begin{array}{c}\mathrm{NaHS} / \mathrm{Na}_{2} \mathrm{~S} \text { profoundly increases the } \\
\text { expression or/and the activity of } \\
\text { eNOS }\end{array}$ & [141-144] \\
\hline & $\begin{array}{c}\mathrm{H}_{2} \mathrm{~S} \text { interacts with } \mathrm{NO} \\
\text { synthase to transform } \\
\mathrm{NO} \text { to nitroxyl (HNO) } \\
\downarrow \mathrm{NO} \rightarrow \uparrow \mathrm{HNO}\end{array}$ & [145] & $\begin{array}{l}\mathrm{Na}_{2} \mathrm{~S} \text { augmented NO production in } \\
\text { chronically ischemic tissues, by } \\
\text { influencing iNOS and nNOS } \\
\text { expression and stimulating nitrite } \\
\text { reduction to NO via xanthine oxidase } \\
\text { (XO) under hypoxic condition }\end{array}$ & [146] \\
\hline \multicolumn{5}{|c|}{ Potent mechanisms of gastroprotection } \\
\hline $\mathbf{I} / \mathbf{R}$ injury & $\begin{array}{l}\uparrow \text { gastric blood flow } \\
\downarrow \text { lipid peroxidation } \\
\downarrow \text { free radicals } \\
\end{array}$ & [147] & $\begin{array}{l}\downarrow \text { plasma level of IL- } 1 \beta \text { and } \\
\text { TNF- } \alpha \text { mRNA expression }\end{array}$ & [114] \\
\hline \multirow[t]{2}{*}{ WRS injury } & \multirow[t]{2}{*}{$\begin{array}{c}\downarrow \text { lipid peroxidation } \\
\uparrow \text { SOD activity } \\
\uparrow \text { GSH concentration }\end{array}$} & \multirow[t]{2}{*}{ [58] } & $\begin{array}{c}\downarrow \text { acid output, } \uparrow \text { gastric juice } \mathrm{pH} \text { and } \\
\text { mucin concentration, } \uparrow \mathrm{GSH}, \mathrm{CAT} \text { and } \\
\text { SOD enzymes activities }\end{array}$ & [148] \\
\hline & & & $\downarrow$ lipid peroxidation products & [110] \\
\hline Ethanol injury & $\begin{array}{l}\downarrow \text { free radicals } \\
\uparrow \text { prostaglandins } \\
\text { production } \\
\end{array}$ & [149] & $\begin{array}{c}\text { Involvement of } \mathrm{K}_{\text {ATP }} \text { channels, } \\
\text { capsaicin-sensitive nerve fibers and } \\
\text { TRPV1 receptors }\end{array}$ & {$[2]$} \\
\hline \multicolumn{5}{|c|}{ Gastric ulcers healing } \\
\hline & $\begin{array}{l}\text { NO inhibits oxidative } \\
\text { stress leading to } \\
\text { acceleration of chronic } \\
\text { gastric ulcers healing }\end{array}$ & {$[150]$} & $\begin{array}{l}\text { Beneficial effect is not dependent on } \\
\text { NO synthesis and do not occur } \\
\text { through activation of ATP-sensitive } \\
\mathrm{K}^{+} \text {channels }\end{array}$ & [90] \\
\hline
\end{tabular}




\section{Acknowledgments}

Marcin Magierowski is supported by a scholarship for $\mathrm{PhD}$ candidates from Polpharma Scientific Foundation.Experimental part of this paper was supported by a grant from the Jagiellonian University Medical College, Krakow, Poland to Marcin Magierowski (K/DSC/001380).

\section{Conflicts of Interest}

The authors declare no conflict of interest.

\section{References}

1. Brzozowski, T.; Konturek, P.C.; Sliwowski, Z.; Kwiecien, S.; Drozdowicz, D.; Pawlik, M.; Mach, K.; Konturek, S.J.; Pawlik, W.W. Interaction of nonsteroidal anti-inflammatory drugs (NSAID) with Helicobacter pylori in the stomach of humans and experimental animals. J. Physiol. Pharmacol. 2006, 57, 67-79.

2. Medeiros, J.V.R.; Bezerra, V.H.; Gomes, A.S.; Barbosa, A.L.R.; Lima-Júnior, R.C.P.; Soares, P.M.G.; Brito, G.A.C.; Ribeiro, R.A.; Cunha, F.Q.; Souza, M.H.L.P. Hydrogen sulfide prevents ethanol-induced gastric damage in mice: Role of ATP-sensitive potassium channels and capsaicin-sensitive primary afferents neurons. J. Pharmacol. Exp. Ther. 2009, 330, 764-770.

3. Chávez-Piña, A.E.; Tapia-Alvarez, G.R.; Navarrete, A. Inhibition of endogenous hydrogen sulfide synthesis by PAG protects against ethanol-induced gastric damage in the rat. Eur. J. Pharmacol. 2010, 630, 131-136.

4. Wallace, J.L. Prostaglandins, NSAIDs, and gastric mucosal protection: Why doesn't the stomach digest itself? Physiol. Rev. 2008, 88, 1547-1565.

5. Bhatia, V.; Tandon, R.K. Stress and the gastrointestinal tract. J. Gastroenterol. Hepatol. 2005, 20, 332-339.

6. Zhu, A.; Kaunitz, J. Gastroduodenal Mucosal Defense. Curr. Gastroenterol. Rep. 2008, 10, 548-554.

7. Kwiecien, S.; Konturek, P.C.; Sliwowski, Z.; Mitis-Musiol, M.; Pawlik, M.W.; Brzozowski, B.; Jasnos, K.; Magierowski, M.; Konturek, S.J.; Brzozowski, T. Interaction between selective cyclooxygenase inhibitors and capsaicin-sensitive afferent sensory nerves in pathogenesis of stress-induced gastric lesions. Role of oxidative stress. J. Physiol. Pharmacol. 2012, 63, 143-151.

8. Robert, A.; Kane, G.; Reele, S.B. Dose response inhibition in man of meal-stimulated gastric acid secretion by 15(R)-15-methyl prostaglandin E2, given orally. Gut 1981, 22, 728-731.

9. Robert, A.; Leung, F.W.; Guth, P.H. Morphological and functional gastric cytoprotection by prostaglandin in rats receiving absolute ethanol orally. Gut 1992, 33, 444-451.

10. Laine, L.; Takeuchi, K.; Tarnawski, A. Gastric mucosal defense and cytoprotection: Bench to bedside. Gastroenterology 2008, 135, 41-60.

11. Takeuchi, K. Gastric cytoprotection by prostaglandin $\mathrm{E}_{2}$ and prostacyclin: Relationship to EP1 and IP receptors. J. Physiol. Pharmacol. 2014, 65, 3-14. 
12. Mita, M.; Satoh, M.; Shimada, A.; Okajima, M.; Azuma, S.; Suzuki, J.S.; Sakabe, K.; Hara S.; Himeno, S. Metallothionein is a crucial protective factor against Helicobacter pylori induced gastric erosive lesions in a mouse model. Am. J. Physiol. Gastrointest. Liver Physiol. 2008, 294, G877-G884.

13. Konturek, P.C.; Brzozowski, T.; Konturek, S.J. Gut clock: Implication of circadian rhythms in the gastrointestinal tract. J. Physiol. Pharmacol. 2011, 62, 139-150.

14. El Eter, E.; Al Tuwaijiri, A.; Hagar, H.; Arafa, M. In vivo and in vitro antioxidant activity of ghrelin: Attenuation of gastric ischemic injury in the rat. J. Gastroenterol. Hepatol. 2007, 22, 1791-1799.

15. Bülbül, M.; Tan, R.; Gemici, B.; Ongüt, G.; Izgüt-Uysal, V.N. Effect of orexin-a on ischemia-reperfusion-induced gastric damage in rats. J. Gastroenterol. 2008, 43, 202-207.

16. Motawi, T.K.; Abd Elgawad, H.M.; Shahin, N.N. Gastroprotective effect of leptin in indomethacin-induced gastric injury. J. Biomed. Sci. 2008, 15, 405-412.

17. Wang, R. The gasotransmitter role of hydrogen sulfide. Antioxid. Redox Signal. 2003, 5, 493-501.

18. Jasnos, K.; Magierowski, M.; Kwiecien, S.; Brzozowski, T. Carbon monoxide in human physiology-its role in the gastrointestinal tract. Postepy Hig. Med. Dosw. 2014, 68, 101-109.

19. Napoli, C.; Ignarro, LJ. Nitric oxide and pathogenic mechanisms involved in the development of vascular diseases. Arch. Phrm. Res. 2009, 32, 1103-1108.

20. Bryan, N.S.; Bian, K.; Murad, F. Discovery of the nitric oxide signaling pathway and targets for drug development. Front. Biosci. 2009, 14, 1-18.

21. Bian, K.; Murad, F. sGC-cGMP signaling: Target for anticancer therapy. Adv. Exp. Med. Biol. 2014, 814, 5-13.

22. Wallace, J.L.; Del Soldato, P.; Cirino, G.; Muscará, M.N. Nitric oxide-releasing NSAIDs: GI-safe antithrombotics. Drugs 1999, 2, 321-326.

23. Fiorucci, S.; Santucci, L. Distrutti E NSAIDs, coxibs, CINOD and H2S-releasing NSAIDs: What lies beyond the horizon. Dig. Liver Dis. 2007, 39, 1043-1051.

24. Ruddock, M.W.; Hirst, D.G. Pentoxifylline inhibits agonist-induced vasoconstriction in vascular smooth muscle and spontaneous peristalsis in isolated ileum. Oncol. Res. 2005, 15, 81-86.

25. Kuo, P.; Gentilcore, D.; Nair, N.; Stevens, J.E.; Wishart, J.M.; Lange, K.; Gilja, O.H.; Hausken, T.; Horowitz, M.; Jones, K.L.; et al. The nitric oxide synthase inhibitor, Ng-nitro-L-arginine-methylester, attenuates the delay in gastric emptying induced by hyperglycaemia in healthy humans. Neurogastroenterol. Motil. 2009, 21, doi:0.1111/j.1365-2982.2009.01321.x.

26. Konturek, S.J.; Brzozowski, T.; Majka, J.; Pytko-Polonczyk, J.; Stachura, J. Inhibition of nitric oxide synthase delays healing of chronic gastric ulcers. Eur. J. Pharmacol. 1993, 239, 215-217.

27. Breuillard, C.; Cynober, L.; Moinard, C. Citrulline and nitrogen homeostasis: An overview. Amino Acids 2015, 47, 685-691, doi:10.1007/s00726-015-1932-2.

28. Cao, Y.; Mu, J.J.; Fang, Y.; Yuan, Z.Y.; Liu, F.Q. Impact of High Salt Independent of Blood Pressure on PRMT/ADMA/DDAH Pathway in the Aorta of Dahl Salt-Sensitive Rats. Int. J. Mol. Sci. 2013, 14, 8062-8072.

29. Böger, R.H.; Bode-Böger, S.M.; Szuba, A.; Tsao, P.S.; Chan, J.R.; Tangphao, O.; Blaschke, T.F.; Cooke, J.P. Asymmetric dimethylarginine (ADMA): A novel risk factor for endothelial dysfunction: Its role in hypercholesterolemia. Circulation 1998, 98, 1842-1847. 
30. Böger, R.H. The emerging role of ADMA as a novel cardiovascular risk factor. Cardiovasc. Res. 2003, 59, 824-833.

31. Briet, M.; Burns, K.D. Chronic kidney disease and vascular remodeling: Molecular mechanisms and clinical implications. Clin. Sci. 2012, 123, 399-416.

32. Das, U.N.; Repossi, G.; Eynard, A.R. L-arginine, NO and asymmetrical dimethylarginine in hypertension and type 2 diabetes. Front. Biosci. 2011, 16, 13-20.

33. Magierowski, M.; Jasnos, K.; Sliwowski, Z.; Surmiak, M.; Krzysiek-Maczka, G.; Ptak-Belowska, A.; Kwiecien, S.; Brzozowski, T. Exogenous asymmetric dimethylarginine (ADMA) in pathogenesis of ischemia-reperfusion-induced gastric lesions: Interaction with protective nitric oxide (NO) and calcitonin gene-related peptide (CGRP). Int. J. Mol. Sci. 2014, 15, 4946-4964.

34. Kwiecień, S.; Ptak-Belowska, A.; Krzysiek-Mączka, G.; Targosz, A.; Jasnos, K.; Magierowski, M.; Szczyrk, U.; Brzozowski, B.; Konturek, S.J.; Konturek, P.C.; et al. Asymmetric dimethylarginine, an endogenous inhibitor of nitric oxide synthase, interacts with gastric oxidative metabolism and enhances stress-induced gastric lesions. J. Physiol. Pharmacol. 2012, 63, 515-524.

35. Mourad, F.H.; Khuri, M.; Shouaib, F.; Nassar, C.F. Protective effect of the nitric oxide donor molsidomine on indomethacin and aspirin-induced gastric injury in rats. Eur. J. Gastroenterol. Hepatol. 2000, 12, 81-84.

36. Wybrańska, I.; Miszczuk-Jamska, B.; Baczyńska, E.; Goldsztajn, P.; Sowa, G.; Przewłocki, R.; Gryglewski, R.; Dembińska-Kieć, A. Influence of SIN-1 and sodium nitroprusside (NANP) on OX-LDL metabolism in macrophages. J. Physiol. Pharmacol. 1994, 45, 387-397.

37. Styś, T.; Styś, A.; Paczwa, P.; Szczepańska-Sadowska, E.; Lipkowski, A.W. Decreased hypotensive respinsiveness to nitric oxide donor $S$-nitroso- $N$-acetyl D,L-penicillamine (SNAP) in spontaneously hypertensive (SHR) rats. J. Physiol. Pharmacol. 1998, 49, 37-49.

38. Konturek, S.J.; Konturek, P.C. Role of nitric oxide in digestive system. Digestion 1995, 56, 1-13.

39. Szlachcic, A.; Bilski, R.; Dziaduś-Sokolowska, A.; Michalski, J.; Mroczka, J. The effect of nitric oxide donors and L-arginine on the gastric electrolyte barrier. J. Physiol. Pharmacol. 2001, 52, 211-220.

40. Konturek, P.C.; Brzozowski, T.; Meixner, H.; Ptak, A.; Hahn, E.G.; Konturek, S.J. Central and peripheral neural aspects of gastroprotective and ulcer healing effects of lipopolysaccharides. J. Physiol. Pharmacol. 2001, 52, 611-623.

41. Jackson, L.M.; Wu, K.C.; Mahida, Y.R. Cyclooxygenase (COX)-1 and COX-2 in normal, inflamed and ulcerated human gastric mucosa. Gut 2000, 47, 762-770.

42. Peskar, B.M. Role of cyclooxygenase isoforms in gastric mucosal defense. J. Physiol. Pharmacol. 2000, 95, 3-9.

43. Hawkey, C.J. COX-1 and COX-2 inhibitors. Best Pract. Res. Clin. Gastroenterol. 2001, 15, 801-820.

44. Ambrosini, M.V.; Mariucci, G.; Rambotti, M.G.; Tantucci, M.; Covarelli, C.; de Angelis, L.; del Soldato, P. Ultrastructural investigations on protective effects of NCX 4016 (nitroaspirin) on macrovascular endothelium in diabetic Wistar rats. J. Submicrosc. Cytol. Pathol. 2005, 37, 205-213. 
45. Fiorucci, S.; Mencarelli, A.; Meneguzzi, A.; Lechi, A.; Renga, B.; del Soldato, P.; Morelli, A.; Minuz, P. Co-administration of nitric oxide-aspirin (NCX-4016) and aspirin prevents platelet and monocyte activation and protects against gastric damage induced by aspirin in humans. J. Am. Coll. Cardiol. 2004, 44, 635-641.

46. Emanueli, C.; van Linthout, S.; Salis, M.B.; Monopoli, A.; del Soldato, P.; Ongini, E.; Madeddu, P. Nitric oxide-releasing aspirin derivative, NCX 4016, promotes reparative angiogenesis and prevents apoptosis and oxidative stress in a mouse model of peripheral ischemia. Arterioscler. Thromb. Vasc. Biol. 2004, 24, 2082-2087.

47. Brzozowski, T.; Konturek, P.C.; Konturek, S.J.; Sliwowski, Z.; Drozdowicz, D.; Kwiecień, S.; Pajdo, R.; Ptak, A.; Pawlik, M.; Hahn, E. Gastroprotective and ulcer healing effects of nitric oxide-releasing non-steroidal anti-inflammatory drugs. Dig. Liver Dis. 2000, 32, 583-594.

48. Fiorucci, S.; Santucci, L.; Federici, B.; Antonelli, E.; Distrutti, E.; Morelli, O.; Renzo, G.D.; Coata, G.; Cirino, G.; Soldato, P.D.; et al. Nitric oxide-releasing NSAIDs inhibit interleukin-1 $\beta$ converting enzyme-like cysteine proteases and protect endothelial cells from apoptosis induced by TNFa. Aliment Pharmacol. Ther. 1999, 13, 421-435.

49. Takeuchi, K.; Ukawa, H.; Konaka, A.; Kitamura, M.; Sugawa, Y. Effect of nitric oxide-releasing aspirin derivative on gastric functional and ulcerogenic responses in rats: Comparison with plain aspirin. J. Pharmacol. Exp. Ther. 1998, 286, 115-121.

50. Konturek, P.C.; Brzozowski, T.; Ptak, A.; Kania, J.; Kwiecień, S.; Hahn, E.G.; Konturek, S.J. Nitric oxide releasing aspirin protects the gastric mucosa against stress and promotes healing of stress-induced gastric mucosal damage: Role of heat shock protein 70. Digestion 2002, 66, 160-172.

51. Wallace, J.L.; McKnight, W.; Wilson, T.L.; del Soldato, P.; Cirino, G. Reduction of shock-induced gastric damage by a nitric oxide-releasing aspirin derivative: Role of neutrophils. Am. J. Physiol. 1997, 273, G1246-G1251.

52. Naito, Y.; Takagi, T.; Handa, O.; Yoshikawa, T. Lipid hydroperoxide-derived modification of proteins in gastrointestinal tract. Subcell Biochem. 2014, 77, 137-148.

53. Guzik, T.J.; Olszanecki, R.; Sadowski, J.; Kapelak, B.; Rudziński, P.; Jopek, A.; Kawczyńska, A.; Ryszawa, N.; Loster, J.; Jawień, J.; et al. Superoxide dismutase activity and expression in human venous and arterial bypass graft vessels. J. Physiol. Pharmacol. 2005, 56, 313-323.

54. Konaka, A.; Nishijima, M.; Tanaka, A.; Kunikata, T.; Kato, S.; Takeuchi, K. Nitric oxide, superoxide radicals and mast cells in pathogenesis of indomethacin-induced small intestinal lesions in rats. J. Physiol. Pharmacol. 1999, 50, 25-38.

55. Kwiecień, S.; Pawlik, M.W.; Brzozowski, T.; Konturek, P.C.; Śliwowski, Z.; Pawlik, W.W.; Konturek, S.J. Nitric oxide (NO)-Releasing aspirin and other (NO) donors in protection of gastric mucosa against stress. J. Physiol. Pharmacol. 2008, 59, 103-115.

56. Wada, K.; Kamisaki, Y.; Kitano, M.; Kishimoto, Y.; Nakamoto, K.; Itoh, T. A new gastric ulcer model induced by ischemia-reperfusion in the rat; role of leukocytes on ulceration in rat stomach. Life Sci. 1996, 59, 295-301.

57. Kourie, J.I. Interaction of reactive oxygen species with ion transport mechanisms. Am. J. Physiol. 1998, 275, 1-24. 
58. Kwiecień, S.; Jasnos, K.; Magierowski, M.; Śliwowski, Z.; Pajdo, R.; Brzozowski, B.; Mach, T.; Wójcik, D.; Brzozowski, T. Lipid peroxidation, reactive oxygen species and antioxidative factors in the pathogenesis of gastric mucosal lesions and mechanism of protection against oxidative stress-induced gastric injury. J. Physiol. Pharmacol. 2014, 65, 613-622.

59. Orlando, R.C.; Lacy, E.R.; Tobey, N.A.; Cowart, K. Barriers to paracellular permeability in rabbit esophageal epithelium. Gastroenterology 1992, 102, 910-923.

60. Elias, P.M.; McNutt, N.S.; Friend, D.S. Membrane alterations during cornification of mammalian squamous epithelia: A freeze-fracture, tracer, and thin-section study. Anat. Rec. 1977, 189, 577-594.

61. Tobey, N.A.; Argote, C.M.; Awayda, M.S.; Vanegas, X.C.; Orlando, R.C. Effect of luminal acidity on the apical cation channel in rabbit esophageal epithelium. Am. J. Physiol. Gastrointest. Liver Physiol. 2007, 292, G796-G805.

62. Farré, R. Pathophysiology of gastro-esophageal reflux disease: A role for mucosa integrity? Neurogastroenterol. Motil. 2013, 25, 783-799.

63. Tobey, N.A.; Koves, G.; Orlando, R.C. Human esophageal epithelial cells possess an $\mathrm{Na}^{+} / \mathrm{H}^{+}$ exchanger for $\mathrm{H}^{+}$extrusion. Am. J. Gastroenterol. 1998, 93, 2075-2081.

64. Tobey, N.A.; Reddy, S.P.; Khalbuss, W.E.; Silvers, S.M.; Cragoe, E.J., Jr.; Orlando, R.C. $\mathrm{Na}^{+}$-dependent and -independent $\mathrm{Cl}^{-} / \mathrm{HCO}^{3-}$ exchangers in cultured rabbit esophageal epithelial cells. Gastroenterology 1993, 104, 185-195.

65. Layden, T.J.; Schmidt, L.; Agnone, L.; Lisitza, P.; Brewer, J.; Goldstein, J.L. Rabbit esophageal cell cytoplasmic pH regulation: Role of $\mathrm{Na}^{+}-\mathrm{H}^{+}$antiport and $\mathrm{Na}^{+}$-dependent $\mathrm{HCO}^{3-}$ transport systems. Am. J. Physiol. 1992, 263, G407-G413.

66. Orlando, R.C. The integrity of the esophageal mucosa. Balance between offensive and defensive mechanisms. Best Pract. Res. Clin. Gastroenterol. 2010, 24, 873-882.

67. Lanas, A.I.; Blas, J.M.; Ortego, J.; Soria, J.; Sáinz, R. Adaptation of esophageal mucosa to acidand pepsin-induced damage: Role of nitric oxide and epidermal growth factor. Dig. Dis. Sci. 1997, 42, 1003-1012.

68. Lanas, A.; Soteras, F.; Jimenez, P.; Fiteni, I.; Piazuelo, E.; Royo, Y.; Ortego, J.; Iñarrea, P.; Esteva, F. Superoxide anion and nitric oxide in high-grade esophagitis induced by acid and pepsin in rabbits. Dig. Dis. Sci. 2001, 46, 2733-2743.

69. Zayachkivska, O.; Pshyk-Titko, I.; Hrycevych, N.; Savytska, M. New insight into oseophageal injury and protection in physiologically relevant animal models. J. Physiol. Pharmacol. 2014, 65, 295-307.

70. Konturek, P.C.; Brzozowska, I.; Targosz, A.; Pawlik, M.; Kania, J.; Hess, T.; Kwiecien, S.; Konturek, S.J.; Reiter, R.J.; Brzozowski, T. Esophagoprotection mediated by exogenous and endogenous melatonin in an experimental model of reflux esophagitis. J. Pineal Res. 2013, 55, 46-57.

71. Pawlik, M.W.; Kwiecien, S.; Pajdo, R.; Ptak-Belowska, A.; Brzozowski, B.; Krzysiek-Maczka, G.; Strzalka, M.; Konturek, S.J.; Brzozowski, T. Esophagoprotective activity of angiotensin-(1-7) in experimental model of acute reflux esophagitis. Evidence for the role of nitric oxide, sensory nerves, hypoxia-inducible factor-1alpha and proinflammatory cytokines. J. Physiol. Pharmacol. 2014, 65, 809-822. 
72. Ishiyama, F.; Iijima, K.; Asanuma, K.; Ara, N.; Yoshitake, J.; Abe, Y.; Koike, T.; Imatani, A.; Ohara, S.; Shimosegawa, T. Exogenous luminal nitric oxide exacerbates esophagus tissue damage in a reflux esophagitis model of rats. Scand. J. Gastroenterol. 2009, 44, 527-537.

73. Seenan, J.P.; Wirz, A.A.; Robertson, E.V.; Clarke, A.T.; Manning, J.J.; Kelman, A.W.; Gillen, G.; Ballantyne, S.; Derakhshan, M.H.; McColl, K.E. Effect of nitrite delivered in saliva on postprandial gastro-esophageal function. Scand. J. Gastroenterol. 2012, 47, 387-396.

74. Pawlik, M.; Pajdo, R.; Kwiecien, S.; Ptak-Belowska, A.; Sliwowski, Z.; Mazurkiewicz-Janik, M.; Konturek, S.J.; Pawlik, W.W.; Brzozowski, T. Nitric oxide (NO)-releasing aspirin exhibits a potent esophagoprotection in experimental model of acute reflux esophagitis. Role of nitric oxide and proinflammatory cytokines. J. Physiol. Pharmacol. 2011, 62, 75-86.

75. Gyires, K.; Toth, E.V.; Zadori, S.Z. Gut inflammation: Current update on pathophysiology, molecular mechanism and pharmacological treatment modalities. Curr. Pharm. Des. 2014, 20, 1063-1081.

76. Szkudlapski, D.; Labuzek, K.; Pokora, Z.; Smyla, N.; Gonciarz, M.; Mularczyk, A.; Maluch, P.; Okopien, B. The emering role of helminths in treatment of the inflammatory bowel disorders. J. Physiol. Pharmacol. 2014, 65, 741-751.

77. Lamine, F.; Fioramonti, J.; Bueno, L.; Nepveu, F.; Cauquil, E.; Lobysheva, I.; Eutamène, H.; Théodorou, V. Nitric oxide released by Lactobacillus farciminis improves TNBS-induced colitis in rats. Scand. J. Gastroenterol. 2004, 39, 37-45.

78. Kankuri, E.; Hämäläinen, M.; Hukkanen, M.; Salmenperä, P.; Kivilaakso, E.; Vapaatalo, H.; Moilanen, E. Suppression of pro-inflammatory cytokine release by selective inhibition of inducible nitric oxide synthase in mucosal explants from patients with ulcerative colitis. Scand. J. Gastroenterol. 2003, 38, 186-192.

79. Jädert, C.; Phillipson, M.; Holm, L.; Lundberg, J.O.; Borniquel, S. Preventive and therapeutic effects of nitrite supplementation in experimental inflammatory bowel disease. Redox. Biol. 2013, 2, 73-81.

80. Akazawa, Y.; Kubo, M.; Zhang, R.; Matsumoto, K.; Yan, F.; Setiawan, H.; Takahashi, H.; Fujikura, Y.; Ogino, K. Inhibition of arginase ameliorates experimental ulcerative colitis in mice. Free Radic. Res. 2013, 47, 137-145.

81. Roediger, W.E. Review article: Nitric oxide from dysbiotic bacterial respiration of nitrate in the pathogenesis and as a target for therapy of ulcerative colitis. Aliment. Pharmacol. Ther. 2008, 27, 531-541.

82. Stipanuk, M.H.; Beck, P.W. Characterization of the enzymatic capacity for cysteine desulphydration in liver and kidney of the rat. Biochem. J. 1982, 206, 267-277.

83. Swaroop, M.; Bradley, K.; Ohura, T.; Tahara, T.; Roper, M.D.; Rosenberg, L.E.; Kraus, J.P. Rat cystathionine beta-synthase. Gene organization and alternative splicing. J. Biol. Chem. 1992, 267, 11455-11461.

84. Shibuya, N.; Mikami, Y.; Kimura, Y.; Nagahara, N.; Kimura, H. Vascular endothelium expresses 3-mercaptopyruvate sulfurtransferase and produces hydrogen sulfide. Biochem. J. 2009, 146, $623-626$. 
85. Shibuya, N.; Tanaka, M.; Yoshida, M.; Ogasawara, Y.; Togawa, T.; Ishii, K.; Kimura, H. 3-Mercaptopyruvate sulfurtransferase produces hydrogen sulfide and bound sulfane sulfur in the brain. Antioxid. Redox Signal. 2009, 11, 703-714.

86. Dello Russo, C.; Tringali, G.; Ragazzoni, E.; Maggiano, N.; Menini, E.; Vairano, M.; Preziosi, P.; Navarra, P. Evidence that hydrogen sulfide can modulate hypothalamo-pituitary-adrenal axis function: in vitro and in vivo studies in the rat. J. Neuroendocrinol. 2000, 12, 225-233.

87. Wang, R. Two's company, three's a crowd: Can $\mathrm{H}_{2} \mathrm{~S}$ be the third endogenous gaseous transmitter? FASEB J. 2002, 16, 1792-1798.

88. Szabo, C. Hydrogen sulfide and its therapeutic potential. Nat. Rev. Drug Discov. 2007, 6, 917-935.

89. Wallace, J.L. Physiological and pathophysiological roles of hydrogen sulfide in the gastrointestinal tract. Antioxid. Redox Signal. 2010, 12, 1125-1133.

90. Wallace, J.L.; Dicay, M.; McKnight, W.; Martin, G.R. Hydrogen sulfide enhances ulcer healing in rats. FASEB J. 2007, 21, 4070-4076.

91. Abe, K.; Kimura, H. The possible role of hydrogen sulfide as an endogenous neuromodulator. J. Neurosci. 1996, 16, 1066-1071.

92. Qu, K.; Chen, C.P.; Halliwell, B.; Moore, P.K.; Wong, P.T. Hydrogen sulfide is a mediator of cerebral ischemic damage. Stroke 2006, 37, 889-893.

93. Wang, Y.; Jia, J.; Ao, G.; Hu, L.; Liu, H.; Xiao, Y.; Du, H.; Alkayed, N.J.; Liu, C.F.; Cheng, J. Hydrogen sulfide protects blood-brain barrier integrity following cerebral ischemia. J. Neurochem. 2014, 129, 827-838.

94. Jang, H.; Oh, M.Y.; Kim, Y.J.; Choi I.Y.; Yang, H.S.; Ryu, W.S.; Lee, S.H.; Yoon, B.W. Hydrogen sulfide treatment induces angiogenesis after cerebral ischemia. J. Neurosci. Res. 2014, 92, 1520-1528.

95. Mok, Y.Y.P.; Moore, P.K. Hydrogen sulfide is pro-inflammatory in haemorrhagic shock. Inflamm. Res. 2008, 57, 512-518.

96. Fiorucci, S.; Antonelli, E.; Distrutti, E.; Rizzo, G.; Mencarelli, A.; Orlandi, S.; Zanardo, R.; Renga, B.; Di Sante, M.; Morelli, A.; et al. Inhibition of hydrogen sulfide generation contributes to gastric injury caused by anti-inflammatory nonsteroidal drugs. Gastroenterology 2005, 129, $1210-1224$.

97. Zhao, W.; Zhang, J.; Lu, Y.; Wang, R. The vasorelaxant effect of $\mathrm{H}_{2} \mathrm{~S}$ as a novel endogenous gaseous KATP channel opener. EMBO J. 2001, 20, 6008-6016.

98. Bhatia, M. Role of hydrogen sulfide in the pathology of inflammation. Scientifica (Cairo) 2012, 2012, 159680, doi:10.6064/2012/159680.

99. Pálinkás, Z.; Furtmüller, P.G.; Nagy, A.; Jakopitsch, C.; Pirker, K.F.; Magierowski, M.; Jasnos, K.; Wallace, J.L.; Obinger, C.; Nagy, P. Interactions of hydrogen sulfide with myeloperoxidase. Br. J. Pharmacol. 2015, 172, 1516-1532.

100. Li, L.; Bhatia, M.; Zhu, Y.Z.; Zhu, Y.C.; Ramnath, R.D.; Wang, Z.J.; Anuar, F.B.; Whiteman, M.; Salto-Tellez, M.; Moore, P.K. Hydrogen sulfide is a novel mediator of lipopolysaccharide-induced inflammation in the mouse. FASEB J. 2005, 19, 1196-1198. 
101. Collin, M.; Anuar, F.B.; Murch, O.; Bhatia, M.; Moore, P.K.; Thiemermann, C. Inhibition of endogenous hydrogen sulfide formation reduces the organ injury caused by endotoxemia. $\mathrm{Br}$. $J$. Pharmacol. 2005, 146, 498-505.

102. Bhatia, M.; Wong, F.L.; Fu, D.; Lau, H.Y.; Moochhala, S.M.; Moore, P.K. Role of hydrogen sulfide in acute pancreatitis and associated lung injury. FASEB J. 2005, 19, 623-625.

103. Zeng, J.; Lin, X.; Fan, H.; Li, C. Hydrogen sulfide attenuates the inflammatory response in a mouse burn injury model. Mol. Med. Rep. 2013, 8, 1204-1208.

104. Wallace, J.L.; Vong, L.; McKnight, W.; Dicay, M.; Martin, G.R. Endogenous and exogenous hydrogen sulfide promotes resolution of colitis in rats. Gastroenterology 2009, 137, 569-578.

105. Zanardo, R.C.; Brancaleone, V.; Distrutti, E.; Fiorucci, S.; Cirino, G.; Wallace, J.L. Hydrogen sulfide is an endogenous modulator of leukocyte-mediated inflammation. FASEB J. 2006, 20, $2118-2120$.

106. Wallace, J.L. Hydrogen sulfide-releasing anti-inflammatory drugs. Trends Pharmacol. Sci. 2007, 28, 501-505.

107. Blackler, R.; Syer, S.; Bolla, M.; Ongini, E.; Wallace, J.L. Gastrointestinal-sparing effects of novel NSAIDs in rats with compromised mucosal defence. PLOS ONE 2012, 7, e35196.

108. Liu, L.; Cui, J.; Song, C.J.; Bian, J.S.; Sparatore, A.; Soldato, P.D.; Wang, X.Y.; Yan, C.D. H2S-Releasing Aspirin Protects against Aspirin-Induced Gastric Injury via Reducing Oxidative Stress. PLoS ONE 2012, 7, e46301.

109. Cipriani, S.; Mencarelli, A.; Bruno, A.; Renga, B.; Distrutti, E.; Santucci, L.; Baldelli, F.; Fiorucci, S. Activation of the bile acid receptor GPBAR1 protects against gastrointestinal injury caused by non-steroidal anti-inflammatory drugs and aspirin in mice. Br. J. Pharmacol. 2013, 168, 225-237.

110. Lou, L.X.; Geng, B.; Du, J.B.; Tang, C.S. Hydrogen sulfide-induced hypothermia attenuates stress-related ulceration in rats. Clin. Exp. Pharmacol. Physiol. 2008, 35, 223-228.

111. Magierowski, M.; Jasnos, K.; Kwiecien, S.; Drozdowicz, D.; Surmiak, M.; Strzalka, M.; Ptak-Belowska, A.; Wallace, J.L.; Brzozowski, T. Endogenous prostaglandins and afferent sensory nerves in gastroprotective effect of hydrogen sulfide against stress-induced gastric lesions. PLoS ONE. 2015, 10, e0118972, doi:10.1371/journal.pone.0118972.

112. Yonezawa, D.; Sekiguchi, F.; Miyamoto, M.; Taniquchi, E.; Honjo, M.; Masuko, T.; Nishikawa, H.; Kawabata. A protective role of hydrogen sulfide against oxidative stress in rat gastric mucosal epithelium. Toxicology 2007, 241, 11-18.

113. Kubo, S.; Kajiwara, M.; Kawabata, A. Dual modulation of the tension of isolated gastric artery and gastric mucosal circulation by hydrogen sulfide in rats. Inflammopharmacology 2007, 15, 288-292.

114. Mard, S.A.; Neisi, N.; Solgi, G.; Hassanpour, M.; Darbor, M.; Maleki, M. Gastroprotective effect of NaHS against mucosal lesions induced by ischemia—Reperfusion injury in rat. Dig. Dis. Sci. 2012, 57, 1496-1503.

115. Guo, C.; Liang, F.; Shah Masood, W.; Yan, X. Hydrogen sulfide protected gastric epithelial cell from ischemia/reperfusion injurybyKeapls-sulfhydration, MAPK dependent anti-apoptosis and NF-кB dependent anti-inflammation pathway. Eur. J. Pharmacol. 2014, 725, 70-78. 
116. Cui, J.; Liu, L.; Zou, J.; Qiao, W.; Liu, H.; Qi, Y.; Yan, C. Protective effect of endogenous hydrogen sulfide against oxidative stress in gastric ischemia-reperfusion injury. Exp. Ther. Med. 2013, 5, 689-694.

117. Mard, S.; Askari, H.; Neisi, N.; Veisi, A. Antisecretory effect of hydrogen sulfide on gastric acid secretion and the involvement of nitric oxide. Biomed. Res. Int. 2014, 2014, doi:10.1155/2014/480921.

118. Takeuchi, K.; Ise, F.; Takahashi, K.; Aihara, E.; Hayashi, S. $\mathrm{H}_{2} \mathrm{~S}$-induced $\mathrm{HCO}^{3-}$ secretion in the rat stomach-involvement of nitric oxide, prostaglandins, and capsaicin-sensitive sensory neurons. Nitric Oxide 2014, 46, 157-164.

119. Nicolau, L.A.; Silva, R.O.; Damasceno, S.R.; Carvalho, N.S.; Costa, N.R.; Aragão, K.S.; Barbosa, A.L.; Soares, P.M.; Souza, M.H.; Medeiros, J.V. The hydrogen sulfide donor, Lawesson's reagent prevents alendronate-induced gastric damage in rats. Braz. J. Med. Biol. Res. 2013, 46, 708-714.

120. Wallace, J.L.; Caliendo, G.; Santagada, V.; Cirino, G. Markedly reduced toxicity of a hydrogen sulphide-releasing derivative of naproxen (ATB-346). Br. J. Pharmacol. 2010, 159, 1236-1246.

121. Wallace, J.L.; Ferraz, J.G.; Muscara, M.N. Hydrogen Sulfide: An Endogenous Mediator of Resolution of Inflammation and Injury. Antioxid. Redox Signal. 2012, 17, 58-67.

122. Shafigullin, M.Y.; Zefirov, R.A.; Sabirullina, G.I.; Zefirov, A.L.; Sitdikova, G.F. Effects of a hydrogen sulfide donor on spontaneous contractile activity of rat stomach and jejunum. Bull. Exp. Biol. Med. 2014, 157, 302-306.

123. Pouokam, E.; Diener, M. Mechanisms of actions of hydrogen sulphide on rat distal colonic epithelium. Br. J. Pharmacol. 2011, 162, 392-404.

124. Ise, F.; Takasuka, H.; Hayashi, S.; Takahashi, K.; Koyama, M.; Aihara, E.; Takeuchi, K. Stimulation of duodenal $\mathrm{HCO}^{3-}$ secretion by hydrogen sulfide in rats: Relation to prostaglandins, nitric oxide and sensory neurons. Acta Physiol. 2011, 201, 117-126.

125. Hirata, I.; Naito, Y.; Takagi, T.; Mizushima, K.; Suzuki, T.; Omatsu, T.; Handa, O.; Ichikawa, H.; Ueda, H.; Yoshikawa, T. Endogenous hydrogen sulfide is an anti-inflammatory molecule in dextran sodium sulfate-induced colitis in mice. Dig. Dis. Sci. 2011, 56, 1379-1386.

126. Matsunami, M.; Tarui, T.; Mitani, K.; Nagasawa, K.; Fukushima, O.; Okubo, K.; Yoshida, S.; Takemura, M.; Kawabata, A. Luminal hydrogen sulfide plays a pro-nociceptive role in mouse colon. Gut 2009, 58, 751-761.

127. Flannigan, K.L.; Agbor, T.A.; Motta, J.P.; Ferraz, J.G.; Wang, R.; Buret, A.G.; Wallace, J.L. Proresolution effects of hydrogen sulfide during colitis are mediated through hypoxia-inducible factor-1 $\alpha$. FASEB J. 2015, 29, doi:10.1096/fj.14-266015.

128. Fasolino, I.; Izzo, A.A.; Clavel, T.; Romano, B.; Haller, D.; Borrelli, F. Orally administered allyl sulfides from garlic ameliorate murine colitis. Mol. Nutr. Food Res. 2015, 59, 434-442.

129. Motta, J.P.; Flannigan, K.L.; Agbor, T.A.; Beatty, J.K.; Blackler, R.W.; Workentine, M.L.; da Silva, G.J.; Wang, R.; Buret, A.G.; Wallace, J.L. Hydrogen sulfide protects from colitis and restores intestinal microbiota biofilm and mucus production. Inflamm. Bowel Dis. 2015, 21, 1006-1017. 
130. Flannigan, K.L.; Agbor, T.A.; Blackler, R.W.; Kim, J.J.; Khan, W.I.; Verdu, E.F.; Ferraz, J.G.P.; Wallace, J.L. Impaired hydrogen sulfide synthesis and IL-10 signaling underlie hyperhomocysteinemia-associated exacerbation of colitis. Proc. Natl. Acad. Sci. USA 2014, 111, 13559-13564.

131. Zayachkivska, O.; Havryluk, O.; Hrycevych, N.; Bula, N.; Grushka, O.; Wallace, J.L. Cytoprotective effects of hydrogen sulfide in novel rat models of non-erosive esophagitis. PLoS ONE 2014, 9, e110688.

132. Stamler, J.S.; Jaraki, O.; Osborne, J.; Simon, D.I.; Keaney, J.; Vita, J.; Singel, D.; Valeri, C.R.; Loscalzo, J. Nitric oxide circulates in mammalian plasma primarily as an S-nitroso adduct of serum albumin. Proc. Natl. Acad. Sci. USA 1992, 89, 7674-7677.

133. Kajimura, M.; Fukuda, R.; Bateman, R.M.; Yamamoto, T.; Suematsu, M. Interactions of multiple gas-transducing systems: Hallmarks and uncertainties of $\mathrm{CO}, \mathrm{NO}$, and $\mathrm{H}_{2} \mathrm{~S}$ gas biology. Antioxid. Redox Signal. 2010, 13, 157-192.

134. Li, C.Q.; Pang, B.; Kiziltepe, T.; Trudel, L.J.; Engelward, B.P.; Dedon, P.C.; Wogan, G.N. Threshold Effects of Nitric Oxide-Induced Toxicity and Cellular Responses in Wild-type and p53-Null Human Lymphoblastoid Cells. Chem. Res. Toxicol. 2006, 19, 399-406.

135. Polhemus, D.J.; Lefer, D.J. Emergence of Hydrogen Sulfide as an Endogenous Gaseous Signaling Molecule in Cardiovascular Disease. Circ. Res. 2014, 114, 730-737.

136. Guzik, T.J.; Korbut, R.; Adamek-Guzik, T. Nitric oxide and superoxide in inflammation and immune regulation. J. Physiol. Pharmacol. 2003, 54, 469-487.

137. Kimura, H. Hydrogen sulfide and polysulfides as biological mediators. Molecules 2014, 19, 16146-16157.

138. Oh, G.S.; Pae, H.O.; Lee, B.S.; Kim, B.N.; Kim, J.M.; Kim, H.R.; Jeon, S.B.; Jeon, W.K.; Chae, H.J.; Chung, H.T. Hydrogen sulfide inhibits nitric oxide production and nuclear factor- $\kappa \mathrm{B}$ via heme oxygenase-1 expression in RAW264.7 macrophages stimulated with lipopolysaccharide. Free Radic. Biol. Med. 2006, 41, 106-119.

139. Bibli, S.I.; Yang, G.; Zhou, Z.; Wang, R.; Topouzis, S.; Papapetropoulos, A. Role of cGMP in hydrogen sulfide signaling. Nitric Oxide 2014, 29, S1089-S1103.

140. Geng, B.; Cui, Y.; Zhao, J.; Yu, F.; Zhu, Y.; Xu, G.; Zhang, Z.; Tang, C.; Du, J. Hydrogen sulfide downregulates the aortic L-arginine/nitric oxide pathway in rats. Am. J. Physiol. Regul. Integr. Comp. Physiol. 2007, 293, R1608-R1618.

141. Chen, P.H.; Fu, Y.S.; Wang, Y.M.; Yang, K.H.; Wang, D.L.; Huang, B. Hydrogen sulfide increases nitric oxide production and subsequent $S$-nitrosylation in endothelial cells. Sci. World J. 2014, 2014, 480387, doi:10.1155/2014/480387.

142. Meng, J.; Ganesan Adaikan, P.; Srilatha, B. Hydrogen sulfide promotes nitric oxide production in corpus cavernosum by enhancing expression of endothelial nitric oxide synthase. Int. J. Impot. Res. 2013, 25, 86-90.

143. Kida, M.; Sugiyama, T.; Yoshimoto, T.; Ogawa, Y. Hydrogen sulfide increases nitric oxide production with calcium-dependent activation of endothelial nitric oxide synthase in endothelial cells. Eur. J. Pharm. Sci. 2013, 48, 211-215.

144. Altaany, Z.; Yang, G.; Wang, R. Crosstalk between hydrogen sulfide and nitric oxide in endothelial cells. J. Cell Mol. Med. 2013, 17, 879-888. 
145. Bełtowski, J.; Jamroz-Wiśniewska, A. Hydrogen sulfide and endothelium-dependent vasorelaxation. Molecules 2014, 19, 21183-21199.

146. Bir, S.C.; Kolluru, G.K.; McCarthy, P.; Shen, X.; Pardue, S.; Pattillo, C.B.; Kevil, C.G. Hydrogen sulfide stimulates ischemic vascular remodeling through nitric oxide synthase and nitrite reduction activity regulating hypoxia-inducible factor-1 $\alpha$ and vascular endothelial growth factor-dependent angiogenesis. J. Am. Heart. Assoc. 2012, 1, e004093.

147. Wada, K.; Kamisaki, Y.; Ohkura, T.; Kanda, G.; Nakamoto, K.; Kishimoto, Y.; Ashida, K.; Itoh, T. Direct measurement of nitric oxide release in gastric mucosa during ischemia-reperfusion in rats. Am. J. Physiol. 1998, 274, G465-G471.

148. Aboubakr, E.M.; Taye, A.; El-Moselhy, M.A.; Hassan, M.K. Protective effect of hydrogen sulfide against cold restraint stress-induced gastric mucosal injury in rats. Arch. Pharm. Res. 2013, 36, 1507-1515.

149. Brzozowski, T.; Konturek, P.C.; Drozdowicz, D.; Konturek, S.J.; Zayachivska, O.; Pajdo, R.; Kwiecień, S.; Pawlik, W.W.; Hahn, E.G. Grapefruit-seed extract attenuates ethanol- and stress-induced gastric lesions via activation of prostaglandin, nitric oxide and sensory nerve pathways. World J. Gastroenterol. 2005, 11, 6450-6458.

150. Brzozowski, T.; Kwiecień, S.; Konturek, P.C.; Konturek, S.J.; Ptak, A.; Mitis-Musioł, M.; Duda, A.; Bielański, W.; Hahn, E.G. Comparison of nitric oxide-releasing NSAID and vitamin C with classic NSAID in healing of chronic gastric ulcers; involvement of reactive oxygen species. Med. Sci. Monit. 2001, 7, 592-599.

(C) 2015 by the authors; licensee MDPI, Basel, Switzerland. This article is an open access article distributed under the terms and conditions of the Creative Commons Attribution license (http://creativecommons.org/licenses/by/4.0/). 